\begin{tabular}{|c|c|c|}
\hline Beitr. Ent. & Keltern & ISSN 0005-805X \\
\hline $\mathbf{5 4 ( 2 0 0 4 ) 1}$ & S. $147-184$ & 28.05 .2004 \\
\hline
\end{tabular}

\title{
The system of the Catocalinae - a historical survey
}

\author{
(Lepidoptera, Noctuidae)
}

LARS KÜHNE and WOLFGANG SPEIDEL

\section{Summary}

The present paper reviews the family-group names of the Catocalinae subfamily within the Noctuidae (Lepidoptera). The underlying concepts and their historical evolution to date are described. All known family group names which were assigned within the Catocalinae are listed. New status: Anumet[ini] Wiltshire, 1976 stat. rev., new synonyms: Lagopter[idae] Kirby, 1897 syn. nov. of Dysgoni[idae] Moore, [1885] 1884-7; Lygephil[ini] Wiltshire, 1976 syn. nov. of Toxocamp[idae] Guenée, 1852; Mocis[ini] Berio, 1992 syn. nov. of Remigi[idae] Guenée, 1852; Pangrapt[inae] Grote, 1882 syn. nov. of Focill[idae] Guenée, 1852; Phacocym[ini] Grote, 1890a syn. nov. of Omopter[idae] Grote, 1895.

\section{Zusammenfassung}

Die vorliegende Arbeit schildert die historische Entwicklung des Systems der Unterfamilie Catocalinae (Noctuidae, Lepidoptera) und enthält eine Liste det Familiengruppennamen, die innerhalb der Catocalinae vergeben wurden. Taxonomische Änderungen: Anumet[ini] Wiltshire, 1976 stat. rev., Lagopter[idae] Kirby, 1897 syn. nov. von Dysgoni[idae] Moore, [1885] 1884-7; Lygephil[ini] Wiltshire, 1976 syn. nov. von Toxocamp[idae] Guenée, 1852; Mocis[ini] Berio, 1992 syn. nov. von Remigi[idae] Guenée, 1852; Pangrapt[inae] Grote, 1882 syn. nov. von Focill[idae] Guenée, 1852; Phaeocym[ini] Grote, 1890a syn. nov. von Omopter[idae] Grote, 1895.

\section{Introduction}

"All natural bodies share with one another a greater or a lesser affinity; the sum of all these affinities forms the epitome of a natural system in abstracto. The proposal of a system in this sense is impossible for the human spirit, in that man is not able to fully investigate the origin and constitutuion of all natural bodies in all their relationships to one another. A list of the natural bodies in accordance with the manner in which they appear to, and are recognised by, the human spirit forms a system in concreto. In abstracto there can be only one system of nature; in concreto there can be as many as the human spirit can judge and interpret. All systems formed in this way are therefore only attempts to investigate the one, unalterable law of nature" (Herrich-Schaeffer 1843).

["Alle Naturkörper stehen zu einander in grösserer oder geringerer Verwandschaft; die Summe aller dieser Verwandschaften bildet den Inbegriff eines Systemes der Natur in Abstracto. Die Aufstellung eines Systemes in diesem Sinne ist für den menschlichen Geist unmöglich, indem er nicht befähigt ist, alle Naturkörper in allen Beziehungen zueinander, alle in ihrem Werden und Seyn vollständig zu erforschen. Eine Zusammenstellung der Naturkörper gemäss der Art und Weise, wie sie dem menschlichen Geiste erscheinen 
und von ihm erkannt werden, gibt ein System in Concreto. In Abstracto kann es also nur ein System der Natur geben; in Concreto so viele, als der menschliche Geist die Natur auf verschiedene Weise auffassen und beurtheilen kann. Alle auf diese Art gebildete Systeme sind also nur Versuch, das eine und unabänderliche Gesetz der Natur zu erforschen" (Herrich-Schäffer, 1843).]

The lepidopterists working systematically were always eager to represent the system in his „natural" arrangement even if they did not know, or could not formulate, ,the one, unalterable law of nature", i.e. mutation recombination and selection as driving forces of evolution. The term 'affinity' was at this time abstract. It was based on similarity alone and not on descendence. For this reason earlier systems could not claim to be constructed exclusively from monophyletic groups. Wing pattern, wing form and position initially stood in the foreground as characters (Borkhausen 1792). Subsequently morphological and anatomical features were increasingly adopted as arguments for taxa and their classification. The importance of the praeimaginal stages was recognised and used at an early stage (see e.g. Denis \& Schiffermüller 1775). The diversity of knowledge and the different opinions of several lepidopterists resulted in different systematic models which are still, in part, not monophyletic and which are thus impossible to falsify. Kitching (1984) vividly demonstrates the historical evolution of schemes for the family Noctuidae.

To date around 35,000 species have been described within the family Noctuidae (Yela \& Kitching 1999), arranged in about 30 subfamilies (Nye 1975, Poole 1989, Fibiger 1990, Heppner 1991, Speidel \& al. 1996a). About 7,000 species with approximately 10,000 described taxa are currently assigned to the subfamily Catocalinae. The systematics and phylogeny of this subfamily represents an unresolved problem (e.g. Kitching 1984; Mitchell \& al. 2000). The principal reasons for this are the historical evolution of the systematics of this subfamily, the enormous species abundance, the insufficiently known morphological variety, the predominant distribution of the genera and species in the tropical and subtropical region as well as the lack of specialists able to survey this group on a world-wide basis. It is safe to assume that the Catocalinae are not a monophylum in their current delimitation.

The most practical approach for a long-term solution of this problem is to distinguish uniform (i.e. monophyletic) groups within the Catocalinae - including all taxa known worldwide - and to examine these separately (Kitching 1984, Berio 1992, Wiltshire 1990, Speidel \& Naumann 1995). Only after this can hypotheses be developed for the kinship of these groups in relation to each other and/or a systematic scheme for the Catocalinae. For the delimitation of uniform groups numerous older and younger models exist which need to be taken into account. In this paper the changing historical evolution is presented and the availability of all known family group names is checked.

\section{Methodology}

The term Catocalinae is used here in the current sense which includes the so-called Ophiderinae (Noctuinae sensu Hampson).

All taxa at the family-group rank as well as the mentioned genera for the Catocalinae were extracted from the relevant literature. The original spelling and original grouping was adopted. As a consequence of the successive development of the systematics with synonyms and 
changing interpretations it is difficult to compare all opinions concerning the arrangement of the genus groups by various authors directly. Therefore the current systematic position of the mentioned species in all publications has been checked. The work of Poole (1989) and Nye (1975) formed the basis for this. If the present species assignment differs from that in the original work, then the current one is added in square brackets []. In case of assignment to another genus, subfamily or family, this is indicated by round brackets ().

The few species of the Catocalinae in the Holarctic region represent only a small section of this world-wide group. Therefore the many travelogues, faunal lists, etc. which include a grouping of the species into suprageneric units from this region without justification were not analysed in so far as no new family-group names are proposed here.

\section{History}

The Catocalinae species placed initially by Linne in the genus Noctua were arranged by Hübner (1816 ff.) in his list into numerous genera. This list forms the basis of our present systematics on a world-wide basis. He consistently employed the taxonomic units genus 'Coitus/Verein), tribus (Familia) and subfamily (Stirps/Stamm) (cf. Hemming 1937: 16). The species of the Catocalinae were arranged by Hübner into 9 subfamilies (table 1).

On the other hand Boisduval $(1829,1833)$ distinguished only two major subunits, the Catocalides (Opbideres, Ophiusa) and the Homopterides (Polydesma, Cyligramma, Erebus). The basic idea of Hübner (1816), to consolidate similar genera into groups was consistently continued by Guenée in the following years. Guenée (1837: 321) initially used the tribus names Catocalidi, Ophiusidi, Noctuoidi and Noctuo-Phaloenidi in his survey of the European Noctuidae. However, he later (Guenée 1841) added further tribus names and their definitions (table 2).

In his following comprehensive study of all known Lepidoptera he significantly revised the system of the Catocalinae (Guenée 1852a,b, 1854) and arranged the known genera into numerous groups. Walker (1857-1858) adopted this system in its entirety. He added the newer species only (in part with new generic terms) and revised the approach at the genus level (table 3).

The systematic studies of Duponchel (1844), Herrich-Schäffer (1843, 1845, 1847), Packard (1869), Meyrick (1895), Tutt (1896), Haworth (1803-28), Lederer (1857) and Smith (1893) predominantly considered the species of Europe and/or North America. The species of the Catocalinae were mostly put only into one family-group because of their small number of species occurring in these areas. As mentioned already, this geographically limited consideration is not suitable for carrying out systematic groupings. This "nordic" viewpoint - to put the Catocalinae into a single subfamily - obviously dominated the systematic thinking and strongly influenced the subsequent development of ideas. A.R. Grote formed in North America an exception to this general tendency. He endeavoured to distinguish family groups and name them. His opinions were of course subject to changes over time. Since his family-group names are today frequently misquoted, we express here the relevant contents of his papers; publications which are often difficult to come by. Fundamentally he subdivided the Noctuae (as a family) into Noctuelitae fasciatae (includes mostly the quadrifine Noctuidae) and Noctuelitae nonfasciatae (all trifine Noctuidae as well as the quadrifine groups mentioned in the table) (Grote 1882, table 4). 
Table 1: Hübner $1816 \mathrm{ff}$.

Tribus (Family)

Stirps (Subfamily)

Coitus (Genus)

Semigeometrae

Plusiae

Inscriptae

Westermanina (Chloephorinae), Euchalcia (Plusiinae), Agrapha (Plusiinae), Symgrapha (Plusiinae), Autographa (Plusinae), Polycbrysia (Plusinae)

Innaratae

Panchrysia (Plusiinae), Diachrysia (Plusiinae), Chrysaspidia [Plusia (Plusiinae)], Chrysodeixis (Plusinae), Erotylae Argyrosticta (Amphipyrinae)

Selectae

Eustrotia (Eustrotiinae), Argyrostrotis [Argyrostrotis, Deltote (Eustrotiinae)], Emmelia (Eustrotiinae)

Promiscuae

Antarchaea [Pbytometra], Hapalotis [Athetis (Amphipyrinae), Cryphia (Bryophilinae), Pseudeustrotia (Pseudeustrotiinae)]

Anthophilae

Proporiae

Glenopteris, Dialithis, Pbrictia

Blandae

Acolasis [Coenipeta, Sympistis], Eublemma (Acontiinae), Porphyrinia [Eublemma (Acontiinae)], Eromene [Eublemma (Acontinae)] Trothisa [Eublemma (Acontinae)], Ecthetis [Eublemma (Acontiinae)]

Flavitinctae Acontia [Xanthodes (Bagisarinae)], Aegle (Stiriinae)

Simulatae

Odice [Eublemma (Acontiinae), Argyrolepidia (Agaristinae), Acantholipes, Xestia (Noctuinae)], Apaustis (Amphipyrinae)

Heliothentes

Alacres

Pbycoma [Pbycoma, Macrodes, Dolichosomastis], Hememplanis

Moderatae Tristes

Helia [Idia (Herminiinae), Coenipeta, Metria], Anthocitta [Coenipetd, Entalia (Euteliinae), Coenipeta

Melipotis [Melipotis, Ercheia], Catepbia, Aedia [Aedia, Tyta], Tarache [Acontia (Acontiinae)], Metria

Celetes

Sympistis [(Cucullinae), Anarta (Hadeninae)], Melicleptria [Schinia (Heliothinae), Protoschinia (Heliothinae),

Heliothis (Heliothinae)], Panemeria (Amphipyrinae or Stirinae), Cbimaera

Meropides

Incomptae

Athysania [Gonodonta], Gonodonta, Trissophaes [Eudocima]

Festivae

Mathas [Eudocima], Rbytia [Eudocima], Otbreis [Eudocima], Acacallis [Eudocima], Corycia [Eudocima]

Elevatae

Ischyia [Ischyia, Phyllodes], Coronis [Ferenta]

Abstrahentes

Ascalaphae

Antaea [Notodontidae]

Frequentes

Astictae [Lygephila], Opbiussa [Ljgephila], Cbtie, Athyrma, Mocis [Mocis, Celiptera], Phoberia [Phoberia, Minucia, Mocis, Ophiusa, Panopoda], Platyia [Platia, Dyomix, Goniapteryx, Pseudophisma], Perasia, Chalciope [Chalciope, Mocis], Paralletia [Parallelia, Grammodes], Dysgonia, Achaea, Bendis [Lesmone, Dysgonia, Serrodes] Concolatatae

Hemeroblemnina, Thermesia [Hemeroblemma], Gorgonia (Druckfehler) [Gorgone], Apistis [Gorgone Anticarsia], Chamina (Druckfehler) [Chanyna, Azeta], Itonia [Itamia] 
Ornatae

Nyctipao [Erebus], Argiva [Erebus], Speiredonia [Speiredonia, Spirana, Onunatophora] Undosae

Otosema [Ascalapha], Symia [Letis, Tbysania], Blosyris [Hemeroblemma], Letis, Gydopis

Lemures

Accendentes

Autophila, Zale, Phaeag'ma [Metria, Zale]

Restinguentes

Blepharoniae

Antbracia [Antbracia, Zale], Apopestes, Mormo (Amphyperinae)

Caerulescentes

Mormonia [Catocala], Catocalla (Druckfehler) [Catocald]

Coccineae

Flavae Eunetis [Catocala], Lamprosia [Catocala], Astiotes [Catocala]

Brephiae

Ephesia [Catocala], Parthenos [Euparthenos], Eucora [Catocala], Corisce [Catocala]

Dubiae

Eutactis [Pbalaenoides (Agaristinae)], Pais [Brephos (Agaristinae)]

Vulgares

Euclidiae

Arbiearis (Geometridae), Allotria

Maculatae

Drasteria [Drasteria, Mocis, Euclidia, Caenurgina], Gonospileia [Euclidia], Callistege [Callistege, Cerocala,

Fasciatae

Caeurgia], Cabmma (Acontiinae), IIypena (Hypeninae)]

Lineatae

Scbinia (Heliothinae), Syntbymia (Amphipyrinae)

Prothymia [Phytometra]

Table 2: Guenée 1841

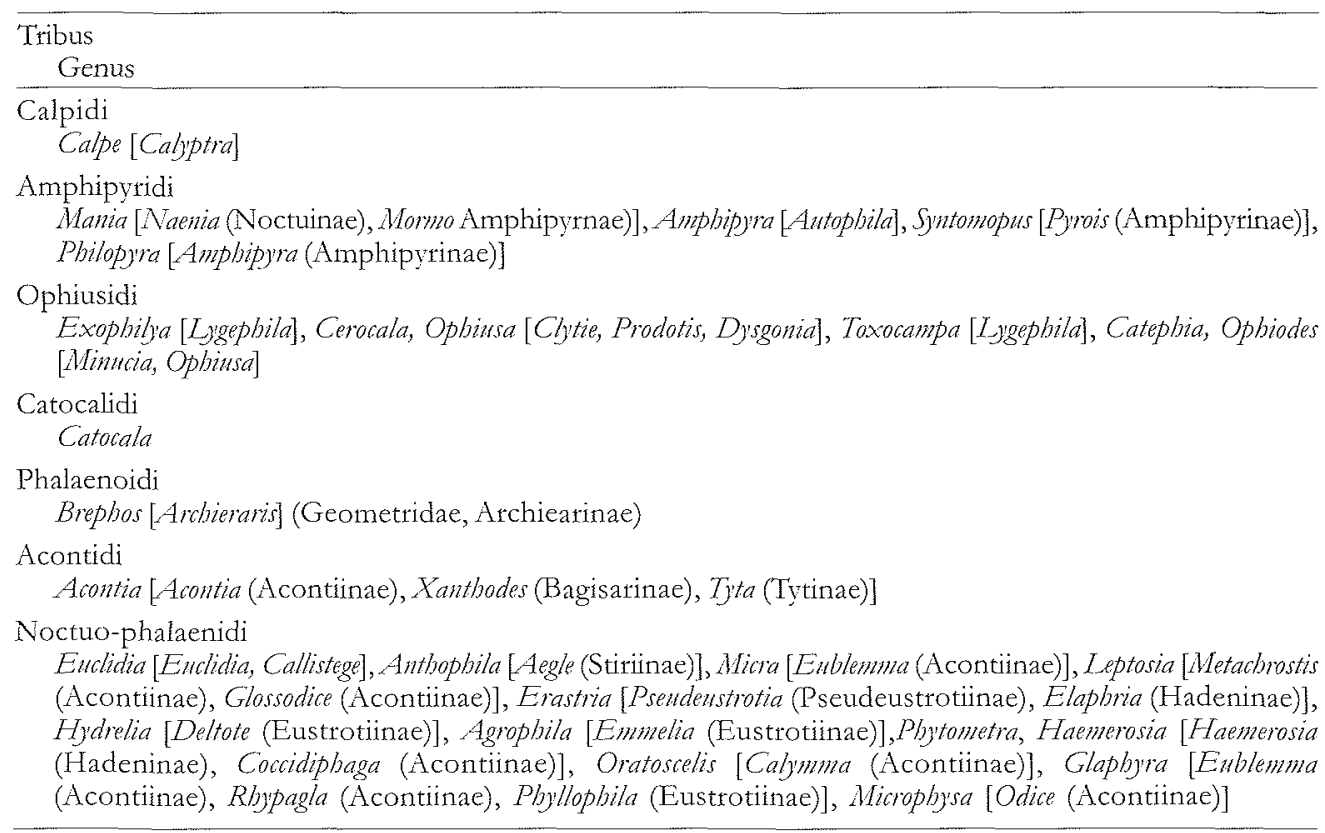


Table 3: Guenée 1852a, b, 1854; Walker 1858 (Phalange Quadrifidae)

Tribus

Family

Genus

Sericeae

Palindidac

Palindia [Eulepidotis], Homodes

Dyopsidae

Dyomyx, Dyops [Dyops, Litoprosopus]

Variegatae

Eriopidae

Emarginea (Amphipyrinae) Cosmodes, Callopistria (Amphipyrinae), Lïneopalpa, Eriopus [Callopistria (Amphipyrinae)], Coxina

Eurhipidae

Pblegetoria [Eutelia (Euteliinae)] Penicillaria (Euteliinae), Eurbipia [Eutelia (Eutelinae)], Anuga (Eutelinae), Ingura [Paectes (Euteliinae)]

Placodidae

Placodes [Eucata (Amphipyrinae)], Diastema (Eustrotiinae)

Plusidae

Abrostola (Plusiinae), Calyptis, Plusia [Autoplusia, Euchalcia, Pobychrysia, Diachrysia ... (alle Plusiinae)], Tbyria [Argrrosticta (Amphipyrinae)], Basilodes (Amphipyrinae), Plusiodonta, Chliara (Notodontidae), Concana, Calyptis

Calpidae

Oraesia, Gonodonta, Calpe [Calyptra], Hapigia (Notodontidae), Diamuna [Darceta (Agaristinae)], Clitis [Dareta (Agaristinae)], Ferenta, Deva [Plusiodonta], Gadera [Plusiodonta], Devena, Ecregma

Hemiceridae

Canodia (Notodontidae), Arcrophora (Chloephorinae), Hemiceras (Notodontidae), Plusiodes [Westermannia (Chloephorinae)], Achantodes (Crambidae), Lymphorta (Notodontidac)

Hyblaeidae

Pbyrodes (Glyphipterigidac), Hyblaea (Hyblaeidae), Nolasena

Gonopteridae

Rhynchodes, Casmophila [Anomis], Anomis, Eriocera, Monogona [Hypsoropha], Thalatta [Thalatta, Anomis], Gomitis [Anomis], Gonoptera [Scoliopteryx], Rusicada [Anomis], Scoedisa [Anomis], Targalla (Euteliinae), Siavana [Panopoda], Scoliopteryx

Intrusae

Amphipyridae

Barydia (Notodontidae), Syntomopus [Pyrois (Amphipyrinae)], Amphipyra (Amphipyrinae), Mania [Naenia (Noctuinae), Mormo (Amphipyrinae)]

Toxocampidae

Exophila [Exophyla, falsche Schreibweise], Spintherops [Apopestes, Autopbila], Toxocampa [Lygeplila], Plecoptera, Herminodes, Chabnata (Hadeninae)

Stilbidae

Stilbia (Amphipyrinae)

Extensae

Polydesmidae

Pantydia, Pandesma, Polydesma, Diatenes

Homopteridae

Pbaeocyma [Zale], Alamis [Pericyma], Xylis [Zale], Homoptera [Zale, Metria], Ypsia [Zale], Anthracia [Psendanthracia], Dugaria [Pericyma, Cortita

Hypogrammidae

Safia [Metria], Yrias [Metria, Kakopoda], Stimmia [Metalectra], Canmpometra [Metria], Cyolodes, Lepidodes, Praxis, Ericeia, Coorba, Caenipeta [Coenipeta, falsche Schreibweise], Hypogramma [Coenipeta, Hypogrammodes], Allotria, Briada [Fetinia], Brana, Eudrapa, Corsa, Gadirtha, [Iscadia (Sarrothripinae)], Cigyna, Harma, Aluatha, Ercheia, Plotheia, Diomea, Crioa, Tbria [Pandesma], Cropia (Amphyperinae) Lusia [Amilaga (Hermininae)] Prospalta, Decelea [Cropia (Amphyperinae)], Elousa, Callyna (Amphypexinae), Prometopus (Amphyperinae) 
Limbatae

Catephidae

Cocytades [Arcte], Catepbia [Catephia, Nagia], Anophia [Aedia], Evggia, Odontodes (Stictopterinae), Stictoptera [Stictoptera, Nagara (Stictopterinae)], Lophoptera (Stictopterinae), Audea, Steiria [Stictoptera (Stictopterinae)], Aucha (Amphipyrinae), Aegilia (Stictopterinae), Minica [Stictoptera (Stictopterinae)], Maceda (Chloephotinae), Paetica (Amphipyrinae)

Bolinidae

Leucanitis [Drasteria], Panula, Bolina [Melipotes, Drasteria], Syneda [Drasteria], Gevespa [Melipotes], Biula [Bulia], Coronta [Melipotes], Diopa

Hypocalidae

Hypocala

Catocalidae

Parthenos [Euparthenos], Catocala, Blenina (Sarrothripinae), Allotria

Ophideridae subf. Ophideridae

Ophideres [Eudicma], Graphigona

Ophideridae subf. Phyllodidae

Miniodes, Pbyllodes, Potamophora [Lscbyia], Lygniodes

Patulae

Erebidae

Oxyodes, Hemeroblemma, Peosina [Hemeroblemma], Blosysris [Hemeroblenma], Brijas [Hemeroblemma], Ramphia, Sypna, Leti, Tavia [Tavia, Speiredonia], Syrnia [Letis], Latebraria, Anisoneura, Thysania, Cyclopis, Erebus

Ommatophoridae

Speiredonia, Sericia [Speiredonia], Dasspodia, Patula [Erebus], Argiva [Erebus], Nyctipao[Erebus], Cyligramma, Ommatophora, Carthaea (eigene austr. Familie Carthaeidae, Bombycoidea), Beregra [Cyclodes]

Hypopyridae

Calliodes, Spirana, Hypopyra [Hypopyra, Spirama], Hamodes, Entomogramma

Bendidae

Hulodides, Emmonodia [Hypopyra], Homaea, Hulodes [Ericeia, Dysgonia]

Bendides

Itonia, Bendis [Lesmone]

Serpentinae

Ophiusidae

Sphingomorpha, Crino, Bardaxima, Iontha, I agoptera [Thyas, Dysgonia, Artena], Ophiodes [Opbiusa, Thyas, Minncia], Opbyx, Psendopbia [Cbrie], Cerbia [Pandesma], Geria [Acbaea], Opbisma [Ophisma, Mimophisma, Dysgonia, Achaea, Heliophisma], Artena, Achaea [Achaea, Ercheia], Serrades, Naxia, Sysgonia], Calesia, Hypaetra [Avatha, Aneurethina], Atbyrma, Opbiusa, [Dysgonia, Parallelia], Agnomonia [Argyrostrotis] Fodina [Fodina, Parachalciope], Grammodes [Grammodes, Chalciope]

Euclididae

Trigonodes, Heterop]gas, Pelamia [Mocis], Cerocala, Drasteria [Caenurgina, Caenurgia], Euclidia [Enclidia, Callistege]

Poaphilidae

Bocula, Lyssia [Phoberia], Phytometra, Poaphila, [Argyrostrotis, Ptichodis, Phoberia, Caenurgina, Panula], Phurys [Ptichodis, Perasia, Celiptera, Nymbis], Celiptera, Mocis, [Celiptera, Perasia, Argyrostrotis], Caenurgia

Remigidae

Remigia [Mocis], Nymbis, Felinia, Isogona, Panopoda, Epidrania, Ceromacra

Pseudo-Deltoidae

Focillidae

Zethes [Zethes, Zethesides, Pangrapta], Thyridospila, Cultripalpa, Focilla [Euclistis, Mazacycla, Claterna], Azatha, Mityas, Azeta]

Amphigonidae

Lacera, Amphigonia [Amphigonia, Eudistis, Phycoma, Ephyrodes], Teratocera [Syllectra], Claterna, Galapha [Eudistis]

Thermesidae

Sympis [Sympis, Platyia, Facidina], Argidia, Cotura [Platyia], Orthogramma [Epitausa], Sany's [Sany's, Condate, Marapana], Heterospila, Thiona, Thermesia [Epidromia, Antiblemma, Anticarsia, Azeta, Melallata, Pbaeoblemna, Epitausa, Maxera, Hypospila, Sarbod, Alzazia [Anticarsia], Hypospila, Azeta, Selenis [Selenisa, Helia], Menecina, Thyriodes, Ephyrodes, Dagarsa [Renodes], Renodes, Gracilodes, Marmorinia [Pangrapta], Mecodina, Agyra, Capnodes, [Antiblemma, Azeta, Erebrostota], Dialithis, Coppansa, Gerisa, Hypenaria [Gongone, Azeta, Antiblemma], Plaxia [Gorgone, Anticarsia, Epitausa, Ephyrades], Marthaniza [Agyra], Pabyna, Empelathra, Talariga, Obroatis, Juncaria, Ginaea [Platyia], Azirista [Argidia], Edyma, Chadaca [Herminodes], Pessida [Pterbemia] 
Deltoidites

Platydidae

Trigonia [Clatema], Macrodes, Ametris, Nemiasca, Epispari], Midila (Crambidae), Masca, Platydia [Yidalpta] Hypenidae

Dichromia [Hypena (Hypeninae)], Rhodina, Rbynchina (Hypeninae), Madopa [Colobocbyla], Pterbemia, Ceraptila [Rhynchina (Hypeninae)], Sarmatia (Hypeninae), Hypena (Hypeninae), Hypenodes [Sclorankia (Strepsimaninae)], Sclmanckia [sic.], HJpenodes (Strepsimaninae)]

Herminidae

Cydopteryx, Rivula (Rivulinae), Sophronia, Simplicia, Herminia, Nodaria, Hydrillodes, Bleptina, Aristaria, Tortricodes, Sitophora, Helia, Glenopteris, Renia, Rejectaria, Physula, Honnogranma, Heterogramma, Mastygophora (Druckfehler) [Mastigophorus (Herminiinae)], Clanyma

Table 4: Grote 1882 "Noctuae" (partim)

Subfamily

Genus

Noctuelitae (Nonfasciatae) (only important subfamilies for the Catocalinae are extracted here)

Anomiinae

Anomis, Pteraetholix [-Amma (Eustrotiinae)], Cbytoryza [Amyna (Eustrotiinae)], Aletia [Alabana, Anomis]

Litoprosopinae

Litoprosopus

Euteliinae

Entelia (Euteliinae), Marasmahs [Marathyssa (Euteliinae)]

Inguritiae

Ingura [Paectes (Euteliinae)]

Calpinae

Calpe [Calyptra], Plusiodonta, Basilodes (Stiriinae), Hesniceras (Notodontidae), Pbiprosopus (misspeling) [Phyprosopus], Hypsoropba

...

\section{Noctuelitae (Fasciatae)}

Catocalinae

Drasteria [Caenurgia], Litosea [Caenurgia], Hypocala, Euclidia [Euclidia, Callistege], Grammodes [Dysgonia], Panula [Panula, Cissusa], Litocala, Symeda [Drasteria], Cimbobolina [Bolina, Melipotis], Melipotis, Stictoptera [Magusa (Amphipyrinae)], Catocala, Allotria, Andrensia [Catocala], Parthenos [Euparthenos]

Ophiderinae

Opbideres [Eudocima]

Toxocampinae

Strenoloma [Spiloloma], Toxocampa [Ljgephila] Synedoida [Drasteria], Phoberia, Celiptera, Psendolimacodes [Fagitana (Amphipyrinae)], Phurys [Ptichodis, Argyrostrotis], Parallelia, Agnomonia [Argyrostrotis] Palindia [Eulepidotis] Harveya [Panopoda] Panopoda, Pleanectptera [Hemeroplanis], Remigia [Mocis], Poapbila [Argyrostrotis, Ptichodis] Trama [Lesmone] Eutorenma [Isogona] Isogona, Capnodes [Antiblemma] Anticarsia, Antiblemma [Metallata.], Agassizia

Erebinae

Erebus [Ascalapha] Thysania, Zale, Pbeocyma [Zale, Pseudantbracia], Homoptera [Zale], Eubolina [Eubolina, Metria, HEteranssa, Coenipeta], Yposia [Zale], Psendantbroecia (Druckfehler) [Psendanthracia], Selenis [Selenisa], Homopyralis, [Metalectra, Toxantrucha], Matigramma, Argillophora (Eustrotinae), Spargaloma (Hypeninae), Hexeris (Thyrididae)

Brotiinae

Brotis [Geometridae]

Pangraptinae

Sylectra, Pangrapta, Pbalaenostola (Hermininae)

'Deltoides'

Psendaglossa [Idia (Herminiinae)], Epizeruxis [Idia (Herminiinae)], Megadyta [Zanclognatha (Herminiinae)], Litognatha [Macrochilo (Herminimae)], Cbytolita (Herminiinae), Pityolita [Zanclognatha (Herminiinae)], Zanclognatha (Herminiinae) Cleptomita [Zanclognatha (Hermininae)], Coptocnemia [Hemeroplanis ('Hypeninae')], Pallachira [Macrocbilo (Hermininae)], Philometra [Phalaenostola (Herminiinae)], Salia [Coloborbyla], Rivula (Rivulinae), Palthis (Hetmininae), Phalaenophana (Herminiinae), Psendorg)ia 
Hypeninae

Sisyrhypena [Macrochilo (Herminiinae)], Capis (Eustrotiinae), Renia (Herminiinae), Tetanolita (Herminiinae), Bleptina (Hermininae), Hypenula (Herminiinae), Lamanaltes (Hypeninae), Hypena (Hypeninae), Eulintreria [Lascoria (Herminiinac)], Dercetis [Redectis (Hermininae)]

Table 5: Grote 1890a

Noctuinae (Noctude nonfasciatae)

Tribus: ...Orthosiini, Caleocampini, Cucullini, Cleophanini, Euteliini (Eutelia, Ripogenus [Eutelia (Eutelinae)]), Ingurini (Ingura [Paectes (Euteliinae)]), Anomiini (Anomis, Aletia [Alabama, Anomis], Pteraetholix [Amyna (Eustrotiinae)], Chytorya [Amyna (Eustrotiinae)]), Litoprosopini (Litoprosopus), Calpini (Calpe [Calyptra]), Stirini, Plusini, Heliothini, Tarachini, Cerathosiini, Eustrotiini, Hyblaeini (Hyblaeidae)

Catocalinae oder "Geometriforme" Noctuidae (Noctnae fasciatae sensu Borkhausen):

Tribus 1: Catocalini (Catocala, Ophideres [Eudocima], Euparthenos ..."The Oploiderinae and Toxocampinae of my) checklist are probably not to be seperated from this tribe...");

Tribus 2: Pheocymini ,this comprise the Erebiinae of my Check List" (Pheocyma [Zale; Psendanthracia], Homoptera [Zale], Perigma, Zethes, Erebus [Ascalapha], Thysania). " Hexeris [Thyrididae], Syllectra, Brotis (Geometridae) probably are to be separated. The tribe Pangraptini (Pangrapta, Phalaenostola Hetmininae)) seetns close ... to Deltoids".

Table 6: Grote 1895 (only "Catocaline moths")

Subfamily

Genus

Euclidiini

Exclidia [Eudidia, Callistege], Drasteria [Caenurgia], Caenurgia, Djsgonia, Panula, Agnomonia, Poaphila, [Argyrostrotis, Ptichodis], Phurys [Ptichodis, Argyrostrotis], Paralletia, Phoberia, Celiptera

Melipotini

Synedoida [Drasteria], Melipotis, Hypocala, Litocala, Syneda, [Drasteria], Cirmobolina [Bolina, Melipotis]

Eulepidotini

Palindia [Entepidotis], Eulepidotis

Sictopterini

Stictoptera [Magusa], Magusa (Amphipyrinae)

Ascalaphini

Ascalapba, Strenalona [Spiloloma], Siavana [Panopoda], Panopoda, Fagitana (Amphipyrinae), Argillophora (Eustrotiinae), Remigia [Mocis], Pleonectoptera [Hemeroplanis], Antiblemma [Metallata], Anticassia

Catocalini

Catocala, Andren'sia [Catocala], Allotria

Ophiderini

Ophideres [Eudocima], Euparthenos

Toxocampini

Toxocampa $[$ Ljgephila $]$, Eutoreuma [Isogona $]$

Thysaniini

Thysania, Letis, Erebus [Ascalapha]

Pheocymini

Pheogma [Zale, Psendanthracid, Zale, Psendantbracia, Ypsia [Zale], Compometra (Exbolina), Trama [Lesmone], Perigyna, Selenis [Selenisa], Yrias [Metria], Homopyralis [Metalectra, [Toxomprudba], Matigranma, Spargalona (Hypeninae)

Pangraptini

Pangrapta, Zethes, Phalaenostola (Herminiinae), Sylectra

Hexerini (Thyrididae)

Hexeris

Boletobiini

Boletobia [Parascotia], Anentia [Laspeyria], Dyaria [Coenodomus, (Pyralidae)], Acherdoa (Amphipyrinae) 
In his following papers Grote increasingly refined and modified his system (Grote 1883, 1889, 1890a, 1890b, 1895, 1896a). (Grote 1890a, table 5). Eventually he subdivided the Catocalinae into 15 tribes (Grote 1895, table 6).

Table 7: Moore 1884-1887

Family Genus

Orthosidae Aramma [Bocula]

Acontiidae ... Brana

Palindiidae Homodes

Plusiidae ... Birtha [Maripa]

Calpidae Oraesia, Arsacia, Calpe [Calyptra]

Hemiceridae Westemanna (Chloephorinae)

Hyblaeidae Hyblaea (Hyblaeidae), Maceda (Chloephorinae)

Gonopteridae Cosmophila [Anomis], Gonitis [Anomis], Rzsicada [Anomis], Thalatta, Falana

Ophiusidae Ophusia [Pantydia, Plecoptesa, Ljugepbila]

Homopteridae Pandesma, Anodapha [Polydesma], Panilla, Girpa [Ericeia], Caduca, Homoptera (of Poole 1989)

Hypogrammidae

Briada [Felinia], Corsa, Callyna (Amphipyrinae), Dimumina, Gadirtha, [Iscadia (Sarrothripinae)], Selepa (Sarrothripinae), Symitha [Nycteola, (Sarrothripinae)], Cletthara [Nanaguna (Sarrothripinae)], Plotheia (Sartothripinae)

Catephidae Arcte, Catephia [Nagia], Melipotes [Ercheia], Anophia [Aedia, Risoba (Sarrothripinae)], Mosara, Vapara [Xylostola (Amphipyrinae)], Stictoptera (Stictopterinae), Aegilia (Stictopterinae), Lophoptera (Stictopterinae), Gyrtona (Stictopterinae)

Hypocalidae Hypocala

Caotocalidae Catocala [Ulotrichopus], Blenina (Sarrothripinae), Aucha (Amphipyrinae)

Ophideridae Otbreis [Eudiona], Argadesa [Eudicma], Maenas [Eudioma], Rbytia [Eudicma], Adris [Eudicma]

Phyllodidae Pbyllodes, Isclbyja, Agonista [Lygniodes]

Erebidae Oxyodes

Ommatophoridae Speiredonia, Sericia [Speiredonia], Patula [Erebus], Argine [Erebus], Noctipao [Erebus]

Hypopyridae Spirama, Iypopyra, Gydodes, Entomogramma, Taramina [Entomogramma], Ortospana 
Bendidae Hulodes

Dysgoniidae Sphingomorpha, Thyas [Thyas, Ophizsa], Minucia [Ophitusa], Ophisma [Ophiusa], Macaldenia [Dysgonia], Achaea [Achaea, Chrysopera], Serrodes, Naxia [Dysgonia], Delgamma, Caranilla [Dysgonia], Pindara [Dysgonia], Psimada, Anerenthina [Avatha, Atbyrma], Ansa [Felinia], Dysgonia, Grammodes, Chalciope, Fodina [Fodina, Attatha], Calesia, Pasipeda [Calesia]

Tinoliidae

Tinolins

Euclidiidae

Trigonodes, Acontholipes

Poaphilidae

Dierna, Arasada (Acontiinae)

Remigiidae Remigia [Mocis], Canninda [Mocis]

Focillidae

Zethes [Tamba, Thermesia (of Poole 1989), Hyperlopba, Parolulis], Egnasia [Egnasia, Adrapsa], Matella [Egnasia], Nagadeba, Daxata, Diomea, Hingula [Rhesala]

Thermesiidae

Platyja, Sympir, Seneratia [Mecodind], Hypospila, Azazia [Anticassia], Sanys [Blasticarbinus], Sonagara (Thyrididae), Dunira, Mestleta [Awtoba] (Acontiinae), Lophomza (Acontiinae), Eublemma (Acontijnae), Zurobata (Acontilnae), Capnodes [Attonda, Capnodes, Saroba, Corgatba (Acontiinae)], Gesonia [Gesonia, Daona]

Amphigoniidae

Lacera, Amplizgonia

Platydidae

Claterna, Episparis

Hypenidae

Corobara, Anoratha (Hypeninae), Dichromia [Hypena (Hypeninae)]...

During the comprehensive study of tropical (oriental) material Moore (1884-87) (table 7) and Cotes \& Swinhoe (1888) (table 8) oriented themselves on the system of Guenée which seems to have come into general recognition at this time. This is also indicated by the studies of Pagenstecher (1894) (table 9) and Kirby (1897) a few years later. At the time of these publications nobody presumably suspected that they would remain the last studies containing detailed subdivisions of the Catocalinae for almost eight decades. Kirby published in 1897 a well-illustrated survey still using Guenée's system, in which he drew a small number of typical representatives for every genus. He initially separated out the Ophiderinae from the quadrifine noctuids and subdivided them strongly (table 10). Why he failed to continue this concept further in his later study (Kirby 1907) remains unexplained. His reasons are unknown and must be a subject for speculation.

About at the same time in the German-speaking region - then a centre of Palaearctic lepidopterology - there was a struggle over guiding principals with respect to systematic work.

Rebel (1898) pointed out the necessity of phylogentic systematics as the basis for a modern system of the Lepidoptera. In his opinion the selection of the morphological features used was decisive and the forming of relationships based on mere similarities was impossible. He hoped this principle would take precedence over the work of Staudinger during the preparation of their joint catalogue (Staudinger \& Rebel 1901). 
Table 8: Cotes \& Swinhoe 1888

Family

Genus

\section{Group Noctues}

Palindidae

Homodes

Diopsidae

Anumeta

Eurhipidae

Rhesala, Targalla (Eutelinae), Penicillaria (Euteliinae), Eutelia (Euteliinae), Antrga (Eutelinnae), Varnia, Baniana, Amte], Chlumetia (Euteliinae), Chlmmetia (Euteliinae)], Metacbrostis (Acontiinae)

Eriopidae

Callopistria (Amphipytinae), Perciana (Hypeninae), Phalga (Euteliinae), Cotanda [Callopistria (Amphipyrinae)], Methorasa [Callopistria (Amphipyrinae)], Lugana [Elusa (Hadeninae)]

Hyblaeidae (eigene Familie)

Hyblaea (Hyblaeidae), Maceda (Chloephorinae)

Gonopteridae

Cosmoplila [Anomis], Arthisma, Rusicada [Anomis, Samara, Mamilia (Chloephorinae)], Gonitis [Anomis], Coarica, Falana, Thalatta, Ossonoba

Amphipyridae

Amphityra (Amphipyrinae), Tambana [Trisuloides (Pantheinae)], Perinaenia, Mitbila, Blenina (Sarrothripinae), Amrella [Blenina (Sartothripinae)], Naenia [Pareuplexia (Ampipyrinae)], Agrotis (Noctuinae), Axiopoena (Arctiidae)

Catocalidae

Catocala [Catocala, Sarbanissa (Agaristinae), Ulotrichopus]

Hypocalidae Hypocala

Toxocampidae Toxocampa [Lysepbila, Rema, Azeta, Pantydia, Plecoptera], Apopestes

Poaphilidae

Poaphila [Poaphila, Argyrostrotis], Ihwad [luza, Talapoptera, Hypospila, Ugia], Borsippa [Bocula], Nasaja [Marcillada], Dierna, Pburys [Loxioda], Tochara [Hypospila], Arasada (Acontiinae)

Xylinindae

Phorica, Litbopbane [Tathotripa (Sarrothripinae), Xylina (Cucullinae)], Xylina [Oglasa], Lyncestis [Melipotis], Epimecia [Rbynchodontodes (Hypeninae), Corymbia (Notodontidae), Cucullia (Cucullinae), Jarasana [Melipotis]

Catephidae

Briarda [Felinia, Lineopalpa], Arcte, Catepbia [Nagia], Hypospila, Aucha, Mosara, Anoplbia [Aedia, Catepbia, Dasygaster (Hadeninae)], Zarima [Catepbia], Vapara [Pandesma, Xylastola (Amphipyrinae)], Stictopiera [Stictoptera (Stictopterinae), Hypotrisula, Lophoptera (Stictopterinae), Laphygma], Erygia, Odontodes (Stictopterinae), Sadarsa [Lopboptera (Stictopterinae)], Gyrtona (Stictopterinae), Lophopiera (Stictopterinae), Aegilia (Stictopterinae), Brana, Atbyrma [Tepbriopis, Anoba]

Hypogrammidae

Callyna (Amphipyrinae), Dinumma, Burdra [Odontodes (Stictopterinae)], Corsa, Hypogramma [Poeta, Perigma], Gadirtha [Plotheia (Sarrothripinae), Iscadia (Sarrothripinae)], Plotheia (Sarrothripinae), Moepa [Perigma], Selepa (Sarrothripinae), Symitha [Nyteola (Sartothripinae), Giaura (Sarrothripinae)], Cletthara [Nanaguna (Sarrothripinae)]

Polydesmidae Bamra, Oromena [Ortopia], Donda, Pandesma [Pandesma, Cbrie, Belciana], Polydesna, Thria [Drasteria]

Homopteridae

Alamis [Pericyma], Caduca, Homoptera [Caduca, Perioma, Antigisa, Zale, Homoptera, Heteropalpia, Gnamptomyx], Panilla, Girpa [Ericeia] 
Ophideridae

Argadesa [Eudocima], Othreis [Eudocima], Maenas [Eudocima], Rbytia [Eudocima], Khadira [Eudocima], Adris [Eudocina], Purbia [Eudocima, Phyllodes [Pbyllodes, Gloriana], Ischyja, Ljgniodes

Erebiidae

Oxyodes, Sypna [Sypna, Daddala, Hypersypnoides, Sypnoides], Anisoneur

Ommatophoridae

Patula [Erebus], Argiva [Erebus], Nyctipao [Erebus, GJligranma] Ommatophora, Entomogramma, Homaea, Speiredonia, Sericia [Speiredonia]

Hypopyridae

Spiramia [Spirama], Hypopyra, Cyclodes, Ortospana

Bendidae

Hulodes, Hamodes

Ophiusidae

Melipotes [Ercheia], Splbingamorpha, Iontha, Thyas [Opbiusa, Artena, Thyas], Ansa [Felinia], Minucia [Oplussia, Serrodes, Celiptera], Ophisma [Hamodes, Ophinsa, Antena, Opbisma, Dysgonia], Platyja, Pindara [Dysgonia, Achaea, Psimada, Serrodes, Naxia [Dysgonia], Delgamma, Caranilla [Dysgonia], Pasipeda [Calesia], Macaldenia [Dysgonia], Catesia, Hypaetra [Anereuthina, Avatha], Anereuthina [Atbyma, Avatha, Megacepbalomana], Dordura, Ophiusa [Dysgonia], Grammodes [Grammodes, Pseudozarba, Chalciope], Fodina [Attatba, Fodina], Artena

Euclididae

Trigonodes, Euclidia, Acantbolipes [Acantholipes, Eublemma (Acontiinae)]

Remigidae

Canninda [Mocis], Remigia [Mocis], Felinia

\section{Group Pseudo-Deltoides}

Focillidae

Hingula [Rhesala, Diascia, Raparna], Zethes [Hyposemansis, Hyperlopha, Tamba, Zetheside, Pangrapta], Thyridospila [Egnasia, Thyrostipa], Saraca [Pangrapta], Harmatelia [Ithmaharela, Catada], Rhaeasena [Radara], Cultripalpa, Egnasia [Egnasia, Eutrogia, Araana, Mecodina, Tamba], Matella [Eghasia], Moscha [HIyertrocia], Daxata [Tadaxa, Rapama], Acbaya [Acharya, Leptotroga], Nagadeba, Diomea

Amphigonidae

Lacera, Amphigonia [Amphigonia, Lopharthrum]

Thermesiidae

Platyja, Sympis [Sympis, Mecodina], Sams [Condate, Marapana, Blasticorrbinus], Thermesia [Condate, Hypospila, Adrapsa, Maxera, Heterospila], Senertia [Mecodina], Dunira, Capnodes [Saroba, Corgatha (Acontiinae), Attonda, Sarobides], Durdara (Thyredidae), Rapama, Selenis [Lophomaza (Acontiinae), Antoba (Acontiinae), Zurabata (Acontinae)], Mestleta [Eublemma (Acontiinae), Autoba (Acontiinae) Saroba, Eublemmoides (Acontiinae), Zurobata (Acontiinae), Lophormza (Acontiinae)], Sonagara (Thyrididae), Azazia [Anticarsia], Marmorinia [Pangrapta, Hypasemansis], Mecodina, Singara [Lophortza (Acontiinae)] Fascellina (Geometridae, Ennominae), Pleurona, Gesonia [Gesonia, Eustrotia (Eustrotiinae), Macna, Ugia, Saroba, Obdora [Tamba], Tamba, Zinna, Sarunga, Doranaga [Negeta (Chloephorinae), Pterogonia (Chloephorinae)]

\section{Group Deltoides}

Platydidae

Masca, Episparis, Clatema

Hypenidae (Hypeninae, ...)

Apparently in the end he only succeeded in part, since the system of the preceding catalogue (Staudinger, in Staudinger \& Wocke 1871) was retained to a large extent. In this widely distributed catalogue an already out of date system was used in particular for the subfamily Catocalinae and was thus presumably cemented as a standard. 
Table 9: Pagenstecher 1894 (Java)

Family

Genus

\section{Noctuae}

Gonopteridae

Gonitis [Anomis]

Homopteridae

Alamis [Pericyma]

Catephidae

Stictoptera (Stictopterinae), Atbyrma, Borsippa [Bocula]

Ophideridae

Ophideres, Pbyllodes, Potamophora [Iscbyja], Plabyja

Erebidae

Sypra, Anisonetra

Ommatophoridae

Pteroyclophora, Spiredonia [Speiredonia], Sericia [Speiredonia], Entomogranma

Hypopyridae Spirama, Fypopyra, Poeciloptera [Hexamitoptera]

Bendidae

Poljidesma [Ericeid]

Ophiusidae Melipotis [Ercheia], Thyas, Ophisma, Dordura, Psimada, Macaldenia [Dysgonia], Naxia [Dysgonia], Ophiusa, Iontha

Euclididae

Trigonodes

Remigidae

Remigia [Mocis]

Thermesidae

$$
\text { Capnodes [7ephriopis] }
$$

\section{Pseudodeltoides}

Focillidae Zethes [Tamba, Vestura]

Amphigonidae Lacera

\section{Deltoides}

Platydidae Episparis

Hypenidae Hypena (Hypeninae), Corcobara (Brontypena)

Herminidae

Nodaria (Herminiinae), Bocana [Simplicia (Herminiinae)], Mastigophora [Oxaenanus (Herminimae)], Avitta, Asthala [Bocana (Herminiinae)], Bleptina (Herminiinae), Egnasia, Rivula (Rivulinae), Simplicia (Herminiinae), Epizenxis [Foveades (Herminiinae)], Sitophora [Amilaga (Herminiinae)], Heterogramma (Hermininae), Helia [Idia (Herminiinae)], Homogramma [Adrapsa (Hermininae)], Hademia [Berthla (Herminiinae)], Selenodes [Ormza (Acontiinae)] 
Table 10: Kirby 1897

Tribus

Family

Genus

I. Noctuae Sericiae

Palindidae

Enlepidotis

Dyopsidae

Litoprosopus

II. Noctuae Variegatae

Eriopidae

Callopistria (Amphipyrinae)

Eurhipidae Eutelia (Euteliinae), Tarnia

Plusiidae Abmatola (Plusinae), Plusia [Diachrysia (Plusiinae), Syngrapha (Plusiinae)]

Calpidae Gonodonta

Hemiceridae Hemiceras (Notodontidae)

Hyblaeidae Hyblaea (Hyblaeidae)

Gonopteridae Scoliopteryx

III. Noctuae Intrusae

Amphipytidae Amphipyra (Amphipyrinae)

Toxocampidae Ophiusa [Ljgephila]

Stilbidae Stilbia (Amphipyrinae)

IV. Noctuae Extensae

Polydesmidae Pantydia

Homopteridae Nephelina [Zale]

Hypogrammidae Anthocitta [Hjpogrammodes]

V. Noctuae Limbatac

Catephidae Aedia [Catephia]

Bolinidae Syneda [Drasteria]

Hypocalidae Hypocala

Catocalidae Catocala

VI. Noctuae Patulae

Erebidae

Peosina, Letis, Thysania, Erebus

Ommatophoridae

Crishona [Erebus], Nyctipao [Erebus], Cyligramma

Hypopyridae Spiramia [Spirama]

Bendidae

Hhllodes 


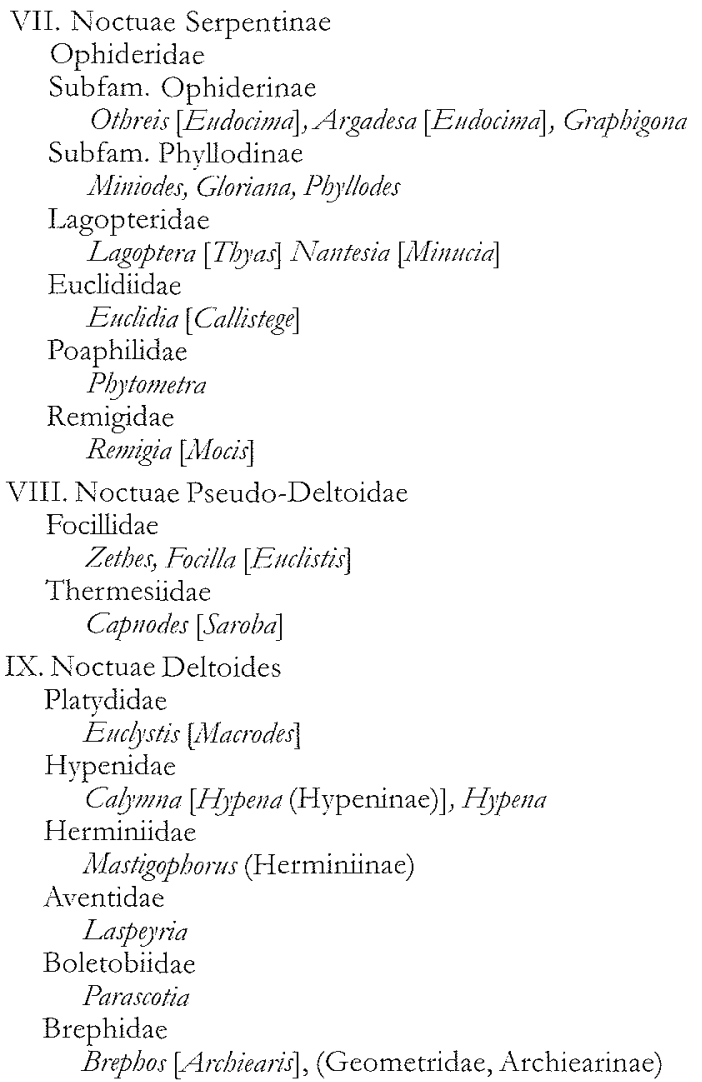

Table 11: Richards (1933)

Group 1: Pangrapta-Isogona series: (Sylectra, Gabara, Isogona, Metalectra, Pangrapta, Dinllagma, Egryrlon) Herminodes-Gabara-Scoleocampa series: (Herminodes, Gabara, Scoleocampa, Psendorgyria, Pbiprosopus)

Group 2: (Strenolonna, Fypsorophora, Alabama, Anomis, Antiblemna, Anticarsia, Calpe, Capnodes, Plusiodonta, Rhespicta) Group 3: Melipotis-Syneda series: (Bolina, Cirrhobolina, Cissusa, Drasteria, Fypocala, Litocala, Melipotis, Pamula, Phoberia, Syneda, Ulos)meda, europ. Leucanitis (wie Syneda))

Group 4: (Eulepidotes, Massala, Toxocampa, Bendis, Coenipeia, Coxina, Epebsia, Epidromia, Eubolina, Euparthenos, Heteranassa, Kakopoda, Matigramma, Panapoda, Safia, Selenis, Sianana, Yrias [Metria], Zale, Zaleops)

Group 5: (Catocala, Erebus, Focillidia, Latebraria, Opbideses, Peosina, Thysania, Thyrissa, (Gonodonta, Litoprosopus, Noropsis, Scolioptery $x)$ )

Group 6: (Argyrostrotis, Caenargia, Celiptera, Cutina, Doryodes, Euclidia, Euclidinera, Pelamia, Phurys)

A fundamentally modified system of the Noctuidae based on a world-wide survey was established by Hampson around the turn of the century. His views became highly influential on subsequent generations of systematic workers and his influence is still felt strongly today. During the preparation of his fauna of British India (Hampson 1894, 1895) his system of the Noctuidae was not yet fully developed. He still accepted the subfamilies Gonopterinae, Palindiinae, Quadrifinae, Focillinae and Deltoidinae. For taxonomic characters he used features like length of the abdomen and the form of the labial palpis (Hampson 1894: 161). As a result the majority of the present 
Catocalinae-species remained in the great block of the quadrifine noctuids. He missed a great opportunity to refine the previous systems during his preparation of the catalogue. He put properly separated taxa - for example the Calpidae - back into the Quadrifinae. Since Hampson was regarded as an authority and a special expert on the Lepidoptera these simplifications, although already understood to be steps backward, were generally accepted. Leech (1900) basically followed Hampson and still distinguished only the Quadrifinae and Focillinae.

In his studies of the fauna of Africa Hampson (1902) evolved his system and separated the present Catocalinae into two subfamilies. The first subfamily - the Catocalinae sensu strictohe first designated as Homopterinae (Nyctipao, Homoptera, Audea ... Ophiusa), then later (Hampson 1910) as Catocalinae (Cyigramma, Calliodes, Ophiusa, Ctenusa, Grammodes, Attatha, Remigia). He arranged the "remains" into the group of his so-called Noctuinae (= Ophiderinae). He characterised his subfamily Catocalinae by a fully-developed vein 5 (M2) in the hindwing which originates from the proximity of the lower discoidal cell and the spined tibia. He consolidated this view for the Catocalinae in his subsequent world-wide account of the Catocalinae (Hampson 1913). He separated the Noctuinae (= Ophiderinae) by the main distinguishing character "without spined middle tibia" from the Catocalinae "with spined middle tibiae". Prout (1921) and Richards (1933) later showed that this feature leads to an artificial group and cannot be employed. Prout considered allied genera, for example Coytodes/Arte or Achaea/Mimophisma, as closely related on the basis of several features, although according to the "spined tibia" character of Hampson they would have had to use the different subfamilies of Catocalinae and/or Noctuinae (= Ophiderinae).

The output of Hampson with respect to the systematics of the Noctuidae is surely undisputed, but for the Catocalinae Hampson cannot be regarded as the precursor of the subject (Kitching 1984). Rather he welded together two monolithic, probably polyphyletic groups or 'grades'; heterogeneous groups whose separation soon proved to be untenable. His methods have been of great advantages for identification, however the main groups he created are not natural ones.

In spite of some criticisms of the features employed for Hampson's groupings - for instance by Forbes (1914) who criticised the presence/absence of vein M2 in the hindwing since intermediate forms exist with an already reduced M2 or by Prout (1921), Gaede (1938) and Draudt (1939) who stated "delimitation of the Catocalinae is unsure, [and the] feature of spined middle tibia insignificant" - his divisions were largely followed (Dyar 1902, 1914, Meyrick 1912, Janse 1917, Mosher 1916, Turner 1920, Barnes \& Benjamin 1923, Lhomme 1923-35, Bang-Haas 1926). They were particularly carried on in the famous publication of Seitz (Warren 1913, Gaede 1936, 1938, Draudt 1935, 1939, Draudt \& Gaede 1944).

This division is mostly employed even now in summarised systematic or faunistic works McDunnough 1938, Zimmerman 1958, Common 1968, Pinhey 1975, Leraut 1980, 1997, Inoue \& al. 1982, Franclement \& Todd in Hodges 1983, Poole 1989, Hacker 1990,1999 , etc.). Here allied groups are often separated by means of the feature "tibiae with or without spines" and thus put into either the Catocalinae or Ophiderinae.

Berio (1960, 1992), Kitching (1984), Speidel \& al. (1996a), Kitching \& Rawlins (1999), and Yela \& Kitching (1999) explicitly showed that this procedure does not form any sort of suitable basis for the formulation of phylogenetic systematic hypotheses for the Catocalinae. Some authors reject completely this insupportable division and take all groups together as the Catocalinae (Hodges \& al. 1983, Common 1990, Sugi 1992, Kobes 1985, Kononenko 1990). Kitching \& Rawlins (1999) also provisionally reject any subdivision of the polyphyletic Catocalinae since the delimitation, composition 
and monophyly of most of their constituent groups is uncertain. They removed only the Calpinae (= Ophiderinae sensu stricto of other authors) from which they recognised the tribes Calpini, Gonopterini and Anomiini. Yela \& Kitching (1999) regarded the Gonopterinae ( = Anomiinae) as a further independent subfamily.

The widespread use of Hampson's classification hinders the development of a consistently phylogenetic system. A main reason for holding on to the old system is the complexity within the highly diverse Catocalinae, such that every attempt to resolve the systematics of this subfamily on a phylogenetic basis appears hopeless.

\section{The new way}

In spite of this dilemma there were repeated attempts to achieve progress in the systematics of the Catocalinae through the investigation of different features (in so far as the quadrifine noctuids were included).

The inclusion of the tympanal-organs (Forbes 1916, Eggers 1919, 1925, Richards 1933) or larval features (Gardner 1947, Forbes 1954, Crumb 1956, Beck 1960) brought out different, but sometimes similar, results through which groups could be constructed. These results depended on the examined material and/or the investigated area.

On the basis of different features, illustrated by Boerner (1939), he later distinguished in his fauna of Germany (Boerner 1944, 1949) again two subfamilies (table 12). Richards' (1933) investigations of the tympanal organ brought out 6 groups in the "Erebinae Catocalinae complex" (table 11). Forbes (1954) also supported the need for a new model and determined a systematic division of the Catocalinae (table 13).

As a result of this development the 150 year old ideas about the systematics of the Catocalinae were picked up again and pushed into a promising direction. One can already speak of a Renaissance when Berio $(1960,1965)$ published a list of phylogenetic units within the Catocalinae. This important step inspired other researchers. Wiltshire (1976) supported these opinions and he separated several tribes in a consistent continuation of this idea and designated them unfortunately only in part according to the rules of the ICZN. Kitching (1984) picked up this approach to the problem and proposed as an initial solution a first step of forming uniform (= monophyletic) genus-groups ( $=$ tribes) within the Catocalinae (incl. Ophiderinae) and a second step of examining these groups separately and later integrating them into a coherent (= consistent-phylogenetic) system.

Table 12: Börner 1944, 1949

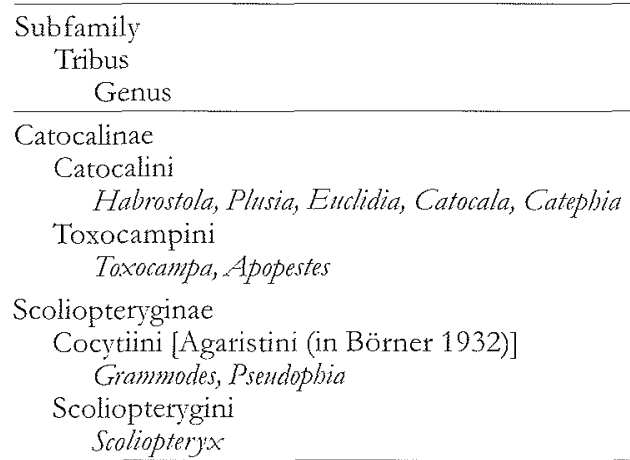


Table 13: Forbes 1954

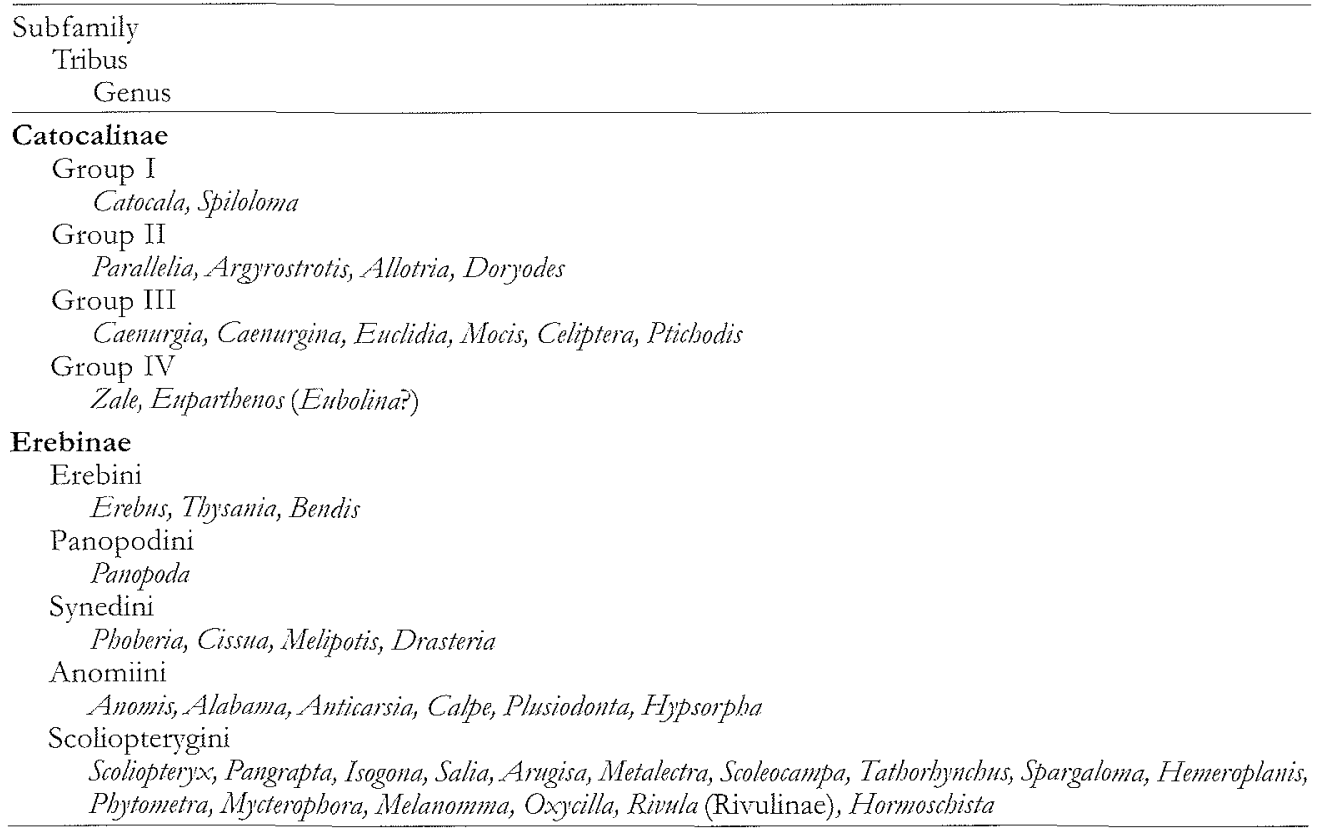

Table 14: Wiltshire 1990

Tribus

Genus

Audeini

Hypotacha, Audea, Ulotrichopus

Achaeini

Acbaea, Prodotis, Caranilla, Dyrgonia, Attatha

Remigini

Trigonodes, Mocis

Ophiusini

Tricbanua, Ophiusa, Clytie

Scodionychini

Scodionyx

Pericymatini

Perionina, Hetropalpia, Tytroca, Gilamptonyx

Anydrophilini

Anjdrophila

Drasteriini

Cerocala, Drasteria

Polydesmini

Polydesma

Lyncestini

Lyncestis

Anumetini

Anmota 
Armadini

Epharmottomena, Iranada, Riadbia, Metopstis, Acrobyla, Asplenia, Ameada

Catephini

Melanepbia, Catephia

Beihaniini

Beihanilia

Crioini

Prionofrontia, Proconis

Ericeini

Ericeia

Sphingomorphini

Sploingomorplia

Pandesmini

Thria

Calesiini

Calesiat

Trisulini

Aucbenisa, Thiacidas, Pterongeta, Sciatta

Toxocampini

Tathorlyynchus, Autophila

Anobini

Anoba

Brevipectenini

Breupecten

Acantholipini

Acantbolipes

Rirulini

Rivula (Rivulinae)

$-$

Colobodyla, Maxera, Elygea

Anomiini

Anomils, Deinopalpus, Radara

Calpini

Africalpe

$-$

Anticarsia, Lacera, Zethesides, Crambiforma

Phytometrini

Pbytometra, Antarchaea, Myana, Nimasia

Table 15: Berio 1992 (Modell IV)

Subfamily

Tizbus

Genus

Catocalinae

Catocalini

Mormonia, Lamprosia, Astiotes, Catocala, Ephesia, Enthetis

Euclidini

Callistege, Euclidia

Mocisini

Caenturgia, Trigonodes, Mocis, Remigia, Remigodiodes, Celiptera, Nymbis, Parahbalciope

DOI: 10.21248/contrib.entomol.54.1.147-184 
Lagopterini

Lagoptera, Dermaleipa

Audeini

Davea, Audea, Ulotrichopus

Ctenusini
Donuctenusa, Ctemusa

Scodionyxini

Acantbonis, Chelecala, Scodionzox

Ophiusini

Opbiusa, Cbtie, Thyas, Anua, Hypanta, Euminucia, Trichanua, Perophiusa, Peramua, Subantra

Achaeini

Prodotis, Gondysia, Grammodes, Achaea, Dysgonia, Chalciope, Ophisma, Caranilla, Macaldenia

Ercheini

Ercheia

Tachosini

Tacbosa, Hypotacha, Metatacha

Ophiderinae

Erebini

Cjligramma, Erebus, Rampbia, Anisoneura, Ascalapha, Symia, Letis, Blosyris, Teinoletis, Gyclopis, Feigeria, Ronania

Drasterini

Cerocala, Protonelipotis, Leucanitis (Aleucanitis), Drasteria

Ophiderini

Pbyllodes, Miniodes, Miniopbyllodes, Lobophyllodes, Eudicma, Adris

Arcteini

Cocgtodes, Pseudoarcte, Arcte, Paracte

Lygephilini Eccrita, Lygepbila

Polydesmini

Contyta, Heteropaipia, Perigma, Moepa, Homaed, Alamis, Dugaria, Matigramma, Beriohansa, Pobydesma, Lophotavia, Viettendia

Phytometrinae

Phytometrini

Phyometra, Antarbaea, Myana, Nimasia

Catephini

Catepbia, Aedia, Nagia, Melanepia

Anomini

Anomis, Rusicada, Deinopalpus, Alabama

Autophilini

Autopbila, Apopestes, Tathorbynchus

Sphingomorphini

Spbingomorpha

Pandesmini

Pandesma

Thiacidini

Thiacides, Trisula, Auchemisa, Trisulana, Pteronycta

Acantholipini

Acantholipes

Ericeini

Enicia

Crioini

Crio, Prionifrontia, Proconis

Anumetini

Antureta

Armadini

Ammada, Acrobyla, Epluamottomena, Metopistis, Asplenia, Drastersides, Riadbia, Iranada

Brevipectenini

Brevipecten 
Table 16: Beck 1996 (author and year in orginal spelling of the source)

\section{Subfamily}

Genus

Catocalinae Guenée, 1837:

Boletobiini Grote, 1895 (Parascotia)

Synedini Forbes, 1954 (Drasteria, Cerocala, Anumeta)

Pangraptini Grote, 1882 (Zethes)

Exophylini trib. nov. (Exopbyla, Perinaenia)

Achaeini Wiltshire, 1976 (Dysgonia, Clytie, Prodotis, Grammodes)

Ophiusini Guenée, 1837 (Minucia, Opbiusa, Arytrira)

Catocalini Guenée, 1837

Catocalina Guenée, 1837 (Simplicala gen. nov, Catocala, Hemigeometra, Bibymena gen. nov, Ephesia)

Aventiina (Tutt, 1902) (Laspejria)

Catephiina Guenée, 1852 (Catephia)

Phytometrini Wiltshire, 1990 [= Poaphilini Tutt, 1902] (Colobody)la, Phytometra)

Toxocampini Guenée, 1852

Euclidiina Guenée, 1852 (Euclidia, Callistege, Gonospileia)

Toxocampina Guenée, 1852 (Rhynchodontodes, Autophila, Cheiropbanes, Eccrita, Craccapbila gen. nov, Ijyephila, Asticta, Tathorlyynchus)

Pandesmini (nach Berio 1992) (Pandesma)

Acantholipini (nach Berio 1992) (Acontholipes)

Polydesmini (nach Berio 1992) (Pericyma)

Scoliopteryginae Spuler, 1908 [recte 1907] (Gonopterinae Herrich-Schäffer, 1845 dito Guenée, 1852)

(= Anomiinae Grote, 1882) (Scoliopteryx)

Ophiderinae Guenée, 1852 (Calyptra)

Aediinae Beck, 1960 (Aedia, Anophia)

Table 17: Leraut 1997

Subfamily Genus

Pangaptini [sic] Zethes

Aventiini

$$
\text { Laspeyria }
$$

Calpini

Calptra, Scoliopteryx

Toxocampini

Tathorbynchus, Apopestes, Autophila, Lygepbila

Tytini

T)

Polydesmini

Pandesma

Aediini

Aedia

Catephïni

Catephia

Drasteriini

Drasteria 


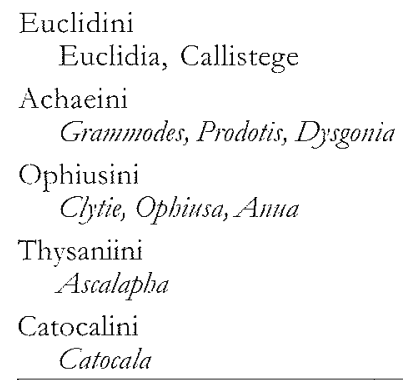

Table 18: Yela 1997

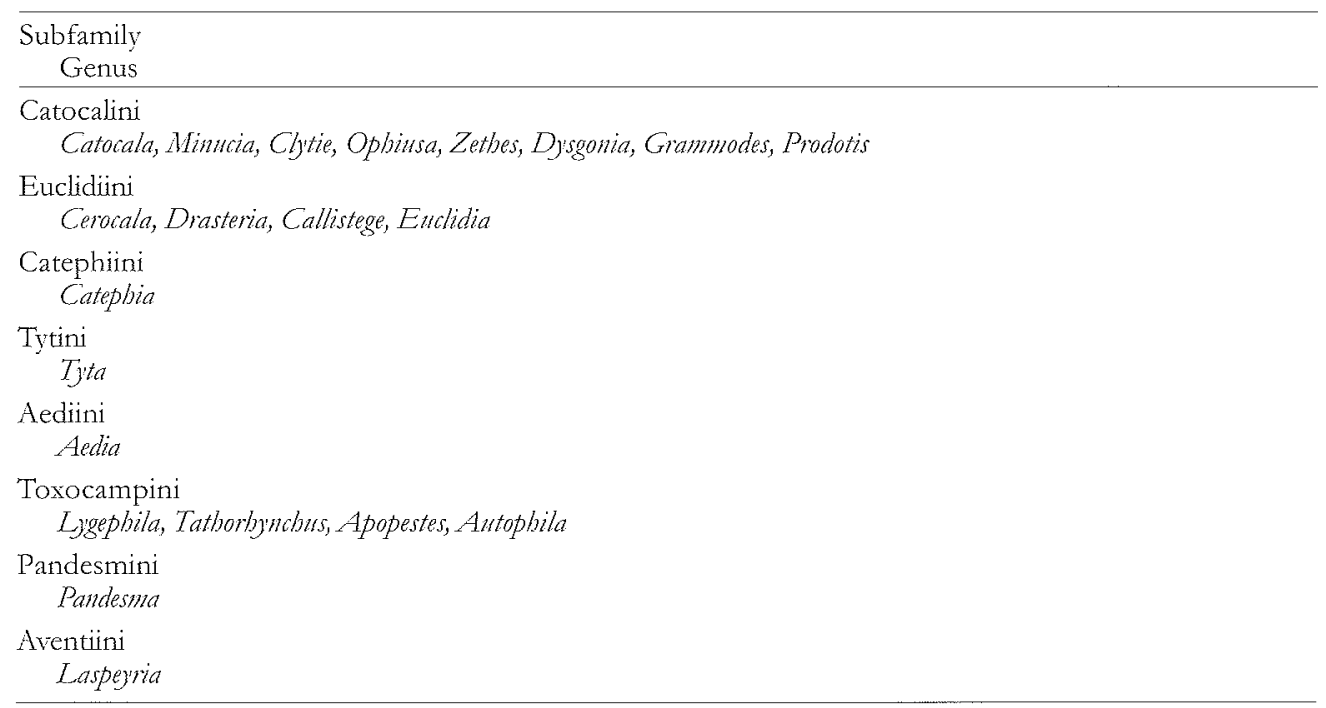

Wiltshire (1990) (table 14) and Berio (1992) (table 15) continued this further and arranged the related genera into tribes. Unfortunately Wiltshire neglected, in part, to give a definition and/or description for his new family-group names according to the ICZN which results that these proposed new family group names remain nomenclatorially unavailable. In order to avoid unnecessary confusion, we have judged the family-group names of Berio (1992) as available described by bibliographical reference to his corresponding "Phyla" in his former publications (Berio 1960, 1965) in accordance with article 13.1.2 ICZN. The serious disadvantage of both these studies is, however, that for every newly described tribe no autapomorphy was designated and thus for these no reasonable grounds for their monophyly exist. But the system outlined in Berio seems to be a good basis which can be built upon due to the partly world-wide consideration and because of the use of features which can be interpreted, in part, as apomorphies. Despite the problems, some of Berio's named tribes have begun to be used in faunistic studies (Speidel \& Hassler 1989, Yela 1997 table 18, Hacker 1999). On the other hand the further qualification of these models based only on the European species (Beck 1996 table 16, Leraut 1997 table 17) is unqualified and is considered here a step backwards (cf. introduction). 


\section{Perspectives}

It is safe to assume that the taxa which are currently united in the Catocalinae (Kitching 1984) are polyphyletic. The adherence to the traditional systematics prevents further progress. Fundamentally necessary is a new way of thinking which rejects the traditional system of the Catocalinae/Ophiderinae in order to exclude "system-constrained" interpretations of results. All available models must be subjected to critical analysis with regard to the features employed. Of course the currently known and employed features are not sufficient to develop a phylogenetic system at the present time. Additional apomorphic features must be sought which can establish supraspecific taxa. New molecular analyses suggest that the Catocalinae can be placed differently within the Noctuoidea (Fang \& al. 2000, Mitchell \& al. 2000). However, the main species block probably forms a monophyletic unit (Speidel \& al. 1996a) and these authors proposed to summarise this block within the tribe Catocalini based on the autapomorphy of "proboscis tip with dorsal sensilla" and the putative autapomorphy of "existence of a corema at the middle tibia" (Barth 1957). The relationships between the individual tribes of the Catocalinae and an answer to the question whether ultimately all tribes (or those except the Catocalini) will be able to remain in this subfamily must to be subject to further investigations.

Investigations which exclusively based themselves on the model of Hampson (1913) and/ or the following treatments in Seitz' encyclopedia (Warren 1913, Gaede 1936-1937, Gaede 1938, Draudt 1935, 1939) or else consider only species for phylogenetic analysis already regarded as closely-related are unsuitable for making progress; as are those considering only the species from a specific area like, for example, Beck (1996). Furthermore it has proven necessary that systematic revisions of the respective group as a first step are necessary in order to exclude the use of synonyms in the phylogenetic analysis.

Furthermore, comparative morphological studies of all taxa of the Catocalinae are necessary. In particular the highly diverse fauna of the tropical and subtropical regions must be included into these investigations. This extensive work can be achieved only by several scientists.

An ,atomization" into countless further tribes should be avoided completely, so long as the degree of affinity of the existing tribes and their possible synonymy remain undetermined. Monophyla characterised by autapomorphies should not be designated until intense investigation has been carried out, in order to avoid nomenclatural confusion in the long run (cf. Speidel \& Hassler 1989).

\section{Catocalinae/Erebinae - Ophiderinae/Othreinae/Noctuinae?}

The diverse designations in the past for the same major group - whose monophyletic status has yet to be established - creates confusion. Most widely used is the name Catocalinae (Catocalidi Boisduval, 1829). Therefore we retain this name here as a nomen protectum. In fact the name Erebinae (Erebidae Leach, 1815) would have priority, but we choose the name Catocalinae as the designated one in accordance with article 23.9.1. of the ICZN to keep the stability (reversal of precedence), since, firstly, no author used Erebinae in priority as name for the family group instead of Catocalinae since 1899 and, second, the younger synonym is in general use. A distinction between Catocalini and Erebini (Nye 1975: 11, Forbes 1954: 356) also appears unnecessary since both groups agree closely in the structure of the proboscis. For the Ophiderinae - which were formerly separated from the Catocalinae because of their lack of spines on the middle tibia- three names are available: Ophiderinae 
(Ophideridae Guenée, 1852), Othreinae Berio, 1955 and Noctuinae (sensu Hampson 1910). The name Ophiderinae unambiguously has priority here and is also in general use. However, in the famous work of Seitz (Draudt 1935, Draudt \& Gaede 1944) the name Noctuinae is generally employed for this group. Berio and Fletcher (1958) proposed Othreinae (Ophiderinae $=$ Noctuinae). This was based on their former opinion for the validity of the generic terms (cf. systematics section). Wiltshire (1971) also still used the name Othreinae.

The use of the name Noctuinae for this group is based on Hampson. He derived the family group names from the oldest generic name in the respective group. The type species of the genera were always the ones which were listed first in the original description of the author (Hampson 1918). For instance Linnaeus (1758) first listed the species strix within the genus Noctua, such that Hampson (1918: 384) understood this as the type species of Noctua and consequently of the Noctuinae. The description of the Phalaena strix by Linnaeus is based, however, on a mixture of two big moths: a south-American Noctuidae (Thysania agriptina Cramer, 1776) and a south-east Asian Cossidae (Xyleutes strix Linnaeus, 1758) (Fletcher \& Nyc 1982: 170). Apparently Hampson interpreted Linnés description in the sense of the Noctuidae, not in the sense of the Cossidae as became later generally accepted. This procedure of Hampson's stands in contrast to present (and previous?) valid rules of nomenclature. The type species of Noctma is promba (official list of the generic names in zoology: name 1057). Therefore the name is employed correctly for the Agrotinae in the sense of Hampson, but this case is not considered here.

\section{Systematics}

In the following section all names of the family-group of the Catocalinae in a wider sense are listed and their taxonomic status is indicated. Names were taken into consideration in the list even if at least one author put them into the Catocalinae, although they undoubtedly represent independent subfamilies. This is valid for example for the Stictopterinae and Euteliinae which are included within the Catocalinae in some older studies.

The main aim is to produce a sound basis for future investigations of the Catocalinae and for the determination of monophyletic groups. It was not possible to check all already existing names of the family group for their systematic status here. This would require an underlying, well-founded hypothesis as to the phylogeny of the entire subfamily and their environment. Only when this hypothesis has been developed can the higher systematics be corrected. There are likely to be different concurrent models in which the supraspecific taxa will be not different in their components but the rank of these supraspecific taxa can be quite different and can only be determined due to historical continuity.

In accordance with article 11.7. ICZN the name of a family group is formed based on the stem word of an available genus name. Article 29. ICZN regulates the determination of the stem word of the type genus and the use of suffixes. In the following list the correct spelling of the stem word stands at the beginning of line. Wrong or invalid spelling is indicated afterwards as "initial/original spelling". The priority status designating suffix of the respective author is separated from the stem word of the family group name by square brackets. An incorrect appendix of the suffix onto the stem word (e.g. $\mathrm{i} / \mathrm{ii}$ ) is corrected without comment. The name giving type genus of the family group stands afterwards in square brackets. 
The ending employed by the authors corresponds to their respective opinion as to the rank within the family group and is in accordance with article 29.2. with respect to the stem word. In this respect the different opinions of several authors to the rank of a taxa are reflected in the different endings. Taxa that are considered to be used in the same sense, but with another rank, are listed with a prefixed equals symbol $\Leftrightarrow$ ) and the reference in which the another rank is assigned to the taxa is quoted with one prefixed "in ". Inspected references in which the taxa was employed in the same rank are stated in round brackets and - where necessary - explanatory remarks are added.

Unavailable names (for example nomina nuda, homonyms) are characterised with a prefixed asterisk $\left(^{*}\right)$. Nomenclatorical changes carried out in this work are expressed in bold type.

According to the ICZN (1999: 111) a nomen nudum is a name "that if published before 1931, fails to conform to Article 12; or, if published after 1930, fails to conform to Article 13." All new descriptions which were published after 1930 must satisfy the provisions of Article 13 of the ICZN and must be accompanied by a description or a definition in words or a bibliographic reference to such a published statement, or they must be proposed as a new replacement name for an available name. Designations assigned before 1930 are not subject to these orders. Here it satisfies in the case of the family group names that the formation of a family-group name is from an available generic name (indication). In accordance with article 11.7.1.1. of the ICZN the use of the stem is meant, then the author used the generic name as valid unless there is evidence to the contrary. These designations are valid without further description. All these orders are valid also for family group names, which some authors unfortunately did not consider (for example Wiltshire). Important for family group names is the fact that in accordance with article 50 a nomen nudum can be made available by a corresponding nomenclatorical action (for example a definition). In such cases, however, this active person is regarded then as the author with the date of his publication.

Furthermore it should be noted that Berio (1992) and Wiltshire (1976, 1990) apparently simply name family groups without giving descriptions, but definitions were given in part, however, in the former publications of Berio (Berio 1960, 1965). We evaluate these cases as a correct nomenclatorical action (description by reference to a source) and consider the names as valid; the reference is referred to correspondingly.

*Acantholip[ini] Wiltshire, 1990: 228 [Acantbolipes Lederer, 1857], nomen nudum according to article 13.1. ICZN, (Berio 1992, Beck 1996, Hacker 1999)

Achae[ini] Wiltshire, 1976: 160 [Achaea Hübner, [1823]], definition of the "Phylum di Achaea" in Berio 1960: 321, synonym of Catocalini (Speidel, Fänger \& Naumann 1997), (Speidel \& Hassler 1989, Berio 1992, Beck 1996, Leraut 1997, Hacker 1999)

Aedi[inae] Beck, 1960: 343 [Aedia Hübner [1823]], independent subfamily (Beck 1960, 1996, Speidel \& al 1996a, Leraut 1997). The genus Catephia (see below) which is habitually similar is not closely allied according to Beck (1996).

*Aglenidae Herrich-Schäffer, [1851] 1845: 435 nomen nudum. The name is not available according to article 13.2 (11.7.1) ICZN, as it is not formed from an available genus-group name.

Amphigoni[idae] Guenée, 1852b: 336 [Ampbigonia Guenée, 1852], (Walker 1858, Cotes \& Swinhoe 1888, Pagenstecher 1894, Moore 1884-87)

*Anob[ini] Wiltshire, 1990: 228 [Anoba Walker, 1858] nomen nudum according to article 13.1. ICZN, (Hacker 1999) 
Anomi[ini] Grote, 1882a: 33 [Anomis Hübner, [1821] 1816], (Grote 1890b, Forbes 1954, Wiltshire 1990, Berio 1992, Hacker 1999, Kitching \& Rawlins 1999, Holloway \& al. 2001)

*Anthophil[idae] Duponchel, 1844: 184 [Anthopbila Ochsenheimer, 1816]. The genus is a homonym of Anthopbila Haworth, 1811 (Lep., Glyphipterygidae) (cf. Nye 1975). Therefore the family-group name is invalid according to article 39 ICZN. The species listed in the original description are presently placed in the genus Eublemma Hübner, [1821], = Anthophilidae in Guené 1852a, = Anthophilinae in Tutt 1896

Anu[ini] Wiltshire, 1976:160 [Anua Walker, 1858], synonym of Ophiusi[ini] according to Speidel \& Hassler (1989), (Leraut 1997), definition of the „Phylum di Anua" in Berio 1960: 315

Anumet[ini] Wiltshire, 1976:161 [Ammeta Walker, 1858], stat. rev., previously treated as synonym of Synedini by Speidel \& Hassler 1989, (Berio 1992)

Anydrophil[ini] Wiltshire, 1976: 161, [Anjdropbila John, 1909], WWiltshire 1990, Hacker 1999, Speidel \& Naumann 1995)

Apopest[ini] Beck, 1996: 15 [Apopestes Fitbner, [1823]. The systematic position of this tribe is unclear, it is erroneously placed in the Cuculliinae by Beck (1996), whereas it is regarded as synonym of Toxocampini by Leraut (1997)

Arcte[ini] Berio, 1992: 294, 298, 301 [Arcte Kollar, 1844], definition of the „Phylum di Arcte" in Berio 1960: 308 and Berio 1965

Armad[ini] Wiltshite, 1961: 626 [Armada Staudinger, 1884], (Wiltshire 1976, 1979, Berio 1992, Hacker 1999)

*Ascalaph[ini] Grote, 1895: 421 [Ascalapha Hübner, [1809]]. Homonym of Ascalaphidae Lefebvre, 1842 (as Ascalaphides) (Neuroptera, Owlflies) which is based on the genus Ascalaphus Fabricius, 1775. The homonymy is first recorded here, however no replacement name is proposed, as the group probably belongs to the Catocalini., = Ascalaphini in Letaut 1997

Aude[ini] Wiltshire, 1990: 202 [Andea Walker, [1858] 1857], definition of the „Phylum di Audea" in Berio 1960: 309, (Berio 1992, Hacker 1999)

*Autophil[ini] Berio, 1992: 295 (as Antophilini), 298 (as Autophilinae), 302 (as Antophilini), [Autophila Hübner, [1823] 1816]. nomen nudum according to article 13.1 ICZN. The name would anyway be nothing but a synonym of Toxocampini.

Aventi[idae] Tutt, 1896: 226 [Alentia Duponchel, 1829, synonym of Laspeyria Germar, 1811], in the meaning of the group around Laspeyria flexula [Denis \& Schiffermuller 1775], = Aventidae in Kirby 1897, $=$ Aventiina in Beck 1996, = Aventiini in Leraut 1997

*Beihani[ini] Wiltshire, 1990: 223 [Beihania Wiltshire 1967], nomen nudum according to article 13.1 ICZN. The genus possibly belongs to the generic group Anumeta, Drasteria, Cerocala, Eremonon. (Hacker 1999)

Bendi[dae] Guenée, 1852b: 206 [Bendis Hübner [1823] 1816], (original spelling: Bendidae, and again, page 211, as 2nd subfamily Bendides s. str. (cf. Hulodides)), (Walker 1858), = Bendidae in Pagenstecher 1894

Boletobi[idae] Guenée, [1858] 1857: 328 [Boletobia Boisduval, 1840, synonym of Parascotia Hübner, [1825]], $=$ Boletobiini in Grote 1895, = Boletobiidae in Kirby 1897, = Boletobiini in Beck 1996, Leraut (1997) erroneously placed the European species in the Rivulinae.

*Bolin[idae] Guenée 1852: 57, [Bolina Duponchel, [1845]. The genus is a homonym of Bolina Rafinesque, 1815 (Mollusca) according to article 53.2 (cf. Nye 1975). Therefore, the family-group name is invalid according to article 39 ICZN. (Walker 1858 , Kirby 1897)

*Brevipecten[ini] Wiltshire, 1990: 228 [Brelipecten Hampson, 1894], nomen nudum according to article 13.1 ICZN, (Berio 1992, Hacker 1999)

Broti[inae] Grote, 1882: 42 [Brotis Hübner, [1821] 1816, synonym of Euxoa Hübner, [1821] (Noctuinae)] replaced by Euxoinae by Warren, 1909

*Calesi[ini] Wiltshire, 1990: 224 [Calesia Guenée, 1852], nomen nudum according to article 13.1 ICZN, (Hacker 1999)

Calp[idi] Guenée, 1841: 247 [Calpe Treitschke, 1825, synonym of Calptra Ochsenheimer, 1816], = Calpidae in Guenée 1852, Walker 1858, Moore 1884-7, Kirby 1897; = Calpinae in Grote 1882, Kitching \& Rawlins 1999, Holloway \& al. 2001, = Calpini in Grote 1890a, 1890b, Wiltshire 1990, Leraut 1997, Hacker 1999; = Calpides in Herrich-Schäffer [1851] 1845, Duponchel 1844 
Catephi[idae] Guenée 1852b: 40 [Catephia Ochsenheimer, 1816], Nalker 1858, Butler 1878, Cotes \& Swinhoe 1888, Noore 1884-7, Pagenstecher 1894, Kirby 1897); = Catephiina in Beck 1996, = Catephiini in Leraut 1997, Wiltshire 1990; = Catephini in Berio 1992, Hacker 1999

Catocal[idi] Boisduval, 1829: 97 [Catocala Schrank, 1802], = Catocalidae in Guenée 1852, Walker 1858, Cotes \& Swinhoe 1888, Moore 1884-7, Tutt 1896, Kirby 1897, = Catocalides in Boisduval 1833, Duponchel 1844, Meyerick 1912, = Catocalina in Beck 1996, = Catocalinae in Grote 1882, 1890a, 1895, Tutt 1896, Swinhoe 1899, Mosher 1916, Lhomme 1923-35, Prout 1928, Börner 1932, 1944, 1949, Wiltshire 1990, Berio 1992, Beck 1996, Holloway \& al. 2001, = Catocalini Grote 1890a, 1895, Börner 1932, 1944, 1949, Berio 1992, Beck 1996, Leraut 1997), = Ereb[idae] Leach, 1815. According to article 23.9.1 ICZN, we propose to give Catocalinae Boisduval, 1829 precedence over Erebinae Leach, 1815 in the case that these taxa are regarded as synonymous in order to maintain stability.

Cocyti[idae] Boisduval, 1874: 46 (original spelling: Cocytides), [Cogtia Boisduval, 1828], synonym of Catocalini (Speidel, Fänger \& Naumann 1997) = Cocytini in Bömer 1944, 1949 = Cocytiidae in Kiriakoff 1951, 1956, = Cocytinae in Holloway \& al. 2001

*Crio[ini] Wiltshire, 1990: 223 [Crioa Walker, [1858] 1857], nomen nudum according to article 13.1 ICZN, (Berio 1992), = Crioni in Hacker 1999

Ctenus[ini] Berio, 1992: 293, 297, 300 [Ctenusa Hampson, 1910], definition of "Phylum di Ctenusa" in Berio 1960: 314

Dicopi[nae] Grote, 1882: 22 [Dicopis Grote, 1874, synonym of Psaphida Walker, 1865]. Psaphida is usually placed in the Cucullinae, however transferred in a separate subfamily Psaphidini Grote, $1896 \mathrm{~b}$ by Poole (1994: 161). Replaced by Psaphidini by Grote, 1896b according to art. 40.2 ICZN. (Grote 1883)

*Dipther[inae] [sic] Hampson, 1918: 384 [*Diphthera Hübner, [1806]]. The family-group name is based on a genus published in a work rejected for nomenclatural purposes (Hübner [1806]). Therefore, the family-group name Diptherinae Hampson is invalid (ICZN article 39). Hübner included in his genus *Diphthera the single species Noctua aprilina Linnaeus sensu Hübner, [1803] ( $=$ Pbalaena alpium Osbeck, 1778). Latreille (1818) accepted the wrong secondary spelling Dipthera [sic] (instead of Diphthera) and added Phalaena ludifica Linnaeus, 1758 (= Trichasea ludifica Linnaeus, 1758) as a member of this genus. The latter species, originally not included in the genus, was erroneously accepted as type-species of *Dipthera [sic] by Hampson. Therefore, the name can be understood in the sense of the present Pantheinae. *Diphthera Hübner, [1806]/*Dipthera Latreille, 1818 has nothing to do with the validly described genus Diphthera Hübner, [1809] whose type-species is the catocaline Diphthera elegans Hübner, [1809] by monotypy, = Diptherinae in Prout 1922

Drasteri[ini] Wiltshire, 1976 [1977]: 160 [Drasteria Hübner, 1818], synonym of Euclididiae Guenée, 1852 (Speidel \& Naumann 1995), definition of the ,Phylum di Cerocala“ in Berio 1960: 302, (Wiltshire 1990, Leraut 1997), = Drasterini in Berio 1992

Dyops[idae] Guenée, 1852a: 281 [Dyops Guenée, 1852], (Walker 1858, Kirby 1897), = Diopsidae [sic] in Cotes \& Swinhoe 1888

Dysgoni[idae] Moore, [1885] 1884-7: 156 [Dygomia Hübner, [1823]1816], Probably this group belongs to the monophylum around Catocala and turns out to be a synonym of Catocalini. = Lagopteridae Kirby, 1897 (syn. nov.)

Erchei[ini] Berio, 1992: 297, 300 [Ercheia Walker, [1858] 1857], definition of the „Phylum di Ercheia“ in Berio 1960: 312

Ereb[idae] Leach, 1815: 134 (original spelling: Erebida) [Erebus Latreille, 1810], here proposed as nomen oblitum. The family-group name Catocal [inae] should be given preference over Ereb[inae] according to article 23.9.3 ICZN. The case must be referred to the Commission. Speidel, Fänger \& Naumann 1997 similarly treat the name as a forgotten senior synonym of Catocalini, (Guenee 1852, Moore 1884-7, Pagenstecher 1894, Kirby 1897), = Erebiidae in Cotes \& Swinhoe 1888, = Erebinae in Grote 1882, Forbes 1954, = Erebini in Forbes 1954, Berio 1992

*Ericei[ini] Wiltshire, 1990: 224 [Ericeia Walker, [1858] 1857], nomen nudum according to article 13.1. ICZN, (Berio 1992, Hacker 1999)

Eriop[ini] Herrich-Schäffer, [1851] 1845: 379 (ursprüngliche Schreibweise: Eriopodides); [Enopus Treitschke, 1825 synonym of Callopistria Hübner, [1821] 1816]. Presently in the subfamily Amphipyrinae. = Eriopidae in Guenée 1852a, Walker 1858, Kirby 1897, Cotes \& Swinhoe 1888 
Euclidi[idae] Guenée, 1852b: 280 [Euclidia Ochsenheimer, 1816], (Walker 1858, Pagenstecher 1894, Moote 1884-7); Speidel \& Naumann (1995) substantiate the monophyly of Drasteria, Euclidia and Tinolius. = Euclidiidae in Tutt 1896, Kirby 1897, = Euclidiina in Beck 1996, = Euclidini in Berio 1992, = Euclidiini in Grote 1895, Speidel \& Naumann 1995, Leraut 1997, = Tinolidae Moore, 1884$7=$ Drasteriini Wiltshire, 1976 [1977], = Synedini Forbes, 1954, $=*$ Goniatides Duponchel, 1944 (nomen nudum)

Eucocyti[idae] Hampson, 1918: 366 [Encoytia Rothschild, 1905], a synonym of Catocalini (Speidel, Fänger \& Naumann 1997)

Eulepidot[inae] Grote, 1895: 421 [Eulepidotis Hübner, 1823] see Palindi[idae] Guenée, 1852, = Eulepidotini in Grote 1895

Eurhipi[idae] Herrich-Schäffer, [1851] 1845: 380 [Eurbipia Boisduval, 1829 a synonym of Eutelia Hübner, [1823] 1816], Replaced by Euteliinae by Grote 1882 according to art. 40.2 ICZN (Guenée 1852a, Walker 1858, Cotes \& Swinhoe 1888, Kirby, 1897)

Euteli[inae] Grote, 1882: 33 [Eutelia Hübner [1823] 1816], an independent subfamily, (Lhomme 1923-35, Prout 1928), = Eutelini in Grote 1890a, 1890b, = Eutelianae in Hampson 1902, 1910, Turner 1920, Seitz 1937, = Euthipidae Herrich-Schäffer, [1851] 1845, = Phlogophorinae sensu Hampson, 1918

Exophyl[ini] Beck, 1996: 11 [Exopbylla Guenée, 1852]

Focill[idae] Guenée, 1852b: 329 [Focilla Guenée, 1852, junior synonym of Eutlystis Hübnet, 1823]. Focillidae Guenee, 1852 is valid for the generic group around Euch'stis according to article 40.1 ICZN, and includes the group around Pangrapta and Zethes. (Walker 1858, Cotes \& Swinhoe 1888, Moore 1884-7, Pagenstecher 1894, Kirby 1897), = Focillinae in Swinhoe 1899, Warren 1913, = Pangrapt[ini] Grote, 1882 (syn. nov.)

*Goniatides Duponchel, 1844: 190 nomen nudum. The name is not available according to article 13.2.

(11.7.1) ICZN, as it is not formed from an available genus-group name then used as valid. The generic group contains Eudidia and can therefore be placed as synonym of Euclid[inae], = Goniatidae in Duponchel 1844, Herrich-Schäffer, [1851] 1845

Gonopter[idae] Herrich-Schäffer, [1850] 1845: 319 [Gonoptera Berthold, 1827, synonym of Scoliopteryx Germar, 1811], = Gonopteridae in Gucnée 1852a, Walker 1858, Cotes \& Swinhoe 1888, Moore 1884-7, Pagenstecher 1894, Kirby 1897, = Gonopterinae in Watren 1913, = Gonopterini in Kitching \& Rawlins 1999. Replaced by Scoliopteryges by Herrich-Schäffer, [1852] 1843-56, according to art. 40.2 ICZN

Hemicerat[idae] Guenée, 1852a: 377 (original spelling: Hemiceridae) [Heimiceras Guenée, 1852], belongs to the Notodontidae, where it is treated as Hemiceratinae. (Walker 1858, Moore 1884-7, Kirby, 1897)

Hexer[ini] Grote, 1895: 422 [Hexeris Grote, 1875], belongs to the Thyrididae

*Homopter[ides] Boisduval, 1833: 108 nomen nudum, the name is not available according to article 13.2 (11.7.1) ICZN, as it is not formed from an available genus-group name then used as valid. (vgl. Omopteridae). = Homopteridae in Guenée 1852

*Homopter[idae] Guenée, 1852b: 1 [Homoptera Guenée, 1852 is an unjustified emendation of Omoptera Guérin-Méneville, [1832] which is a synonym of Zale Hübner, [1818] (Poole 1989)] (Walker 1858, Cotes \& Swinhoe 1888, Moore 1884-7, Pagenstecher 1894, Grote 1895, Kirby 1897). = Phaeocymini Grote, 1890 (syn. nov.), = Homopterinae in Hampson 1902

Hulod[ides] Guenée, 1852b: 206 [Hulodes Guenée, 1852], established as subfamily of Bendidae by Guenée $1852 \mathrm{~b},=$ Bendidae in Cotes \& Swinhoe 1888, Moore 1884-7, Kirby 1897

Hyblae[idae] Guenée, 1852a: 388 [Hyblaea Fabricius, 1793], independent family (Hyblaeidae), (Walker 1858, Cotes \& Swinhoe 1888, Moore 1884-7, Kirby 1897), = Hyblacini in Grote 1890a, 1890b

Hypocallidae] Guenée, 1852b: 73 [Hypocala Guenée, 1852], (Walker 1858, Cotes \& Swinhoe 1888, Moore 1884-7, Kirby 1897)

Hypogramm[idae] Guenée, 1852b: 20 [Hypograntha Guenée, 1852, synonym of Coenipeta Hübner, 1818], (Walker 1858, Cotes \& Swinhoe 1888, Moore 1884-7, 1897), Hypogramm[idae] Guenée, 1852 is valid according to article 40.1. ICZN and must be used for the generic group around Coenipeta.

Hypopyr[idae] Guenée, 1852b: 192 [Hypopyra Guenée, 1852], (Walker 1858, Moore 1884, Cotes \& Swinhoe 1888, Pagenstecher 1894 Kirby, 1897), Berio (1965: 320) includes this group in his definition of the "Phylum di Entomogramma“. 
Ingur[inae] Grote, 1882: 33 [Ingura Guenée, 1852], = Ingurini in Grote 1890a

Lagopter[idac] Kirby, 1897: 171 [Lagoptera Guenée, 1852, synonym of Thjas Hübner, [1824]], syn. nov. of Dysgoni[idae], = Lagopterini in Berio 1992, definition of the "Phylum di Dermaleipa“ in Berio 1965: 298

*Leptosi[idae] Herrich-Schäffer, [1851] 1845: 429 (original spelling: Leptosidae) [Leptosia Guenée, 1841], Herrich-Schäffer, 1845: 431, homonym of Leptosia Hübner, 1818 (Pieridae). Invalid because of the generic homonymy

Litoprosop[inae] Grote, 1882: 33 [Litoprosopus Grote, 1869], = Litoprosopini in Grote 1890a, 1890b

Lygephil[ini] Wiltshire, 1976: 159 [Ljgephila Billberg, 1820, synonym of Taxocampa Guenée, 1841], syn. nov. of Toxocamp [idae] Guenée, 1852 according to article 11.7.1 ICZN, (Berio 1992). Wiltshire mentions the source of the name as „Börner's System“. Börner (1932) only once indicated „Toxocampini [Lygephilini]". In the later editions there is no reference to Lygephilini (Börner 1939, 1944).

*Lyncest[ini] Wiltshire, 1990: 214 [Lyncestis Walker, 1857] nomen nudum according to article $13.1 \mathrm{ICZN}$, (Hacker 1999), Speidel \& Naumann (1995) treat Lyncestini as synonym of Melipotini Grote, 1895.

Melipot[ini] Grote, 1895: 421 [Melipotis Hübner, 1818], =*Lyncestini Wiltshire, 1990, synonymous according to Speidel \& Naumann (1995)

Metoponi[idae] Herrich-Schäffer, [1851] 1845: 386 (original spelling: Metoponidae) [Metoponia Duponchel, [1845], synonym of Aegle Hübner, [1823] (Stiriine)], nomen oblitum, cf. *Anthophil[idae]

Mocis[ini] Berio, 1992: 293, 296, 299 [Mocis Hübner, [1823] 1816], syn. nov. of Remigi[idae] Guenée, 1852 according to article 40.1 ICZN and because of the definition of the "Phylum di Mocis" in Berio 1960: 318 , as he includes the genus Remigia $\mathrm{Gn}$.

Odontod[inac] Hampson, 1918: 192, 383 [Odontodes Guenée, 1852]. Synonym of Stictopterinae (c.g. Inoue 1958)

Ommatophor[idae] Guenée, 1852: 169 [Ommatophora Guenée, 1852], (Walker 1858, Butler 1878, Moore 1884-7, Cotes \& Swinhoe 1888, Pagenstecher 1894, Kirby, 1897). Predominantly, members of the genus Erebits Latreille, 1810 are placed here. Therefore, it is probably a synonym of Catocalini.

Omopter[idae] Boisduval, 1833: 108 (original spelling: Homopterides) [Omoptera Guérin-Méneville, 1832], corrected spelling according to article 32.5 or article 35 ICZN (Speidel \& Naumann 1995), cf. Homopteridae. The name must be used for the generic group around Zale. = Phaeocymini Grote, 1890 (syn. nov.)

Ophider[idae] Guenée, 1852b: 108 [Ophideres Boisduval, 1832], (Walker 1858, Moore 1884-7, Cotes \& Swinhoe 1888, Pagenstecher 1894, Kirby, 1897), = Ophiderinae in Grote 1882, 1890a, Kirby 1897, Prout 1928, Fibiger \& Hacker 1990, Berio 1992, = Ophiderini in Grote 1895

Ophius[idi] Guenée, 1837: 321 (1841:71) [Opbiusa Ochsenheimer, 1816] = Ophiusidae in Herrich-Schäffer 1845, Guenée 1852b, Pagenstecher 1894, Walker 1858, Moore 1884-7, Cotes \& Swinhoe 1888, = Ophiusides in Duponchel 1844, = Ophiusini in Speidel \& Hassler 1989, Wiltshire 1990, Berio 1992, Beck 1996, Leraut 1997, Hacker 1999, = Anuini Wiltshire, 1976

Othre[inae] Berio, 1955: 133 [Othreis Hübner, [1823]], synonym of Ophiderinae (e.g. Leraut 1980). The name was unnecessarily introduced by Berio, as Ophideres Boisduval, 1832 was placed as a synonym of Othreis at that time, and Berio overlooked the permanent validity of the family-group name Ophiderinae according to article 40.1 ICZN. = Othreinae in Berio 1960, Griveaud \& Viette 1961, Wiltshire 1971, 1976

Palindi[idae] Guenée, 1852a: 274 [Palindia Guenée, 1852, synonym of Eulepidotes Hübner, 1823], replaced by Eulepidotinae by Grote, 1895 according to art. 40.2 ICZN (Moore 1884-7), = Palindidae in Walker 1858, Kirby 1897, Cotes \& Swinhoe 1888, = Eulepidotinae Grote, 1895

*Pandesm[ini] Wiltshire, 1990: 224 [Pandesma Guenée, 1852], nomen nudum according to article 13.1. ICZN, (Berio 1992, Beck 1996)

Pangrapt[inae] Grote, 1882: 42 [Pangrapta Hübner, 1818] syn. nov. of Focill[idae] Guenée, 1852, = Pangraptini in Grote 1890a, 1895, Beck 1996, = Pangaptini (misspel.) in Leraut 1997

Panopod[ini] Forbes, 1954: 361 [Panopoda Guenée, 1852]

Pericym[ini] Wiltshire, 1976: 160 (original spelling: Pericymatini) [Perigma Herrich-Schäffer, [1851] 1845], description of the "Phylum di Pericyma" in Berio 1960: 320 and partly in Wiltshire 1970, first available name for the Polydesm[ini] cf. Speidel \& Hassler 1989, (Wiltshire 1990, Leraut 1997)

Phaeocym[ini] Grote, 1890a: 109, 145 (original spelling: Pheocymini) [Pharogma Hübner, 1818], syn. nov. of Omopter[idae] Grote, 1895 
Phlogophor[inae] Hampson, 1918: 190, 383 [Plslogophora Treitschke, 1825]. The denomination Hampson's refers to the Euteliinae and is based on an incorrectly identified type-species of the genus Phlogophora. Hampson accepted Noctua adulatrix Hübner, [1813] as type-species of Phlogoploora, without reference to the earlier designation of Pbalakna meticulosa Linnaeus, 1758 by Duponchel (1829). According to articles 41 and 65.2 ICZN, the Commission had to decide about this name, if the stability of the nomenclature is threatened. In any case, this denomination is not available for the Euteliinae.

Phyllod[idae] Guenée, 1852b: 119 [Phy)/lodes Boisduval, 1832], described as 2nd subfamily of the Ophider[idae] (Walker 1858, Moore 1884-7), = Phyllodinae in Kirby 1897

*Phytometrides Herrich-Schäffer, [1844] 1847: 7 nomen nudum. The name is not available according to article 13.2. (11.7.1) ICZN, as it is not formed from an available genus-group name. Herrich-Schäffer used this denomination clearly for a group within the Geometridee (Herrich-Schäffer 1847 [1844]: 1)

Phytometr[inae] Hampson, 1913: 401 [Pbytometra Haworth, 1809]. The denomination Hampson's refers to the Plusiinae and is based on a misidentified type-species of the genus Phytometra. Hampson accepted Phalaena festucae Linnaeus, 1758 as type-species of Phytometra, without reference to the earlier designation of Noctua aenea Denis \& Schiffermüller, 1775 by Westwood (1840). According to article 41 und 65. 2 ICZN, the Commission had to decide on this name, if the stability of the nomenclature would be threatened. In any case, the denomination is not available for the Plusiinae. = Phytometrinae in Warren 1913, Mosher 1916, Lhomme 1923-35, Draudt 1935, Gaede 1936, 1938

Phytometr[ini] Wiltshire, 1990:232 [Pbytometra Haworth, 1809], eventually a synonym of Poaphillidae, = Phytometrini in Berio 1992, Beck 1996, Hacker 1999, = Phytometrinae in Berio 1992, = Phytometridi in Berio 1992.

*Platydi[dae] Guenée, 1854: 11 [Platydia Guenée, 1854, junior homonym of Platydia Costa, 1852 (Brachiopoda)], (Walker 1858, Moore 1884-7, Cotes \& Swinhoe 1888, Kirby 1897). Family-group name invalid according to article 39 ICZN (Homonymy of the type-genus)

Poaphili[idae] Guenée, 1852b: 295 [Ponphila Guenée, 1852], NWalker 1858, Moore 1884-7, Cotes \& Swinhoe 1888, Kirby 1897). The genus Phytomzetra is included herc by Gucnée. Phytometrini Wiltshire, 1990 is a synonym of Poaphili[idae], if the group proves to be monophyletic. = Poaphiliidae in Tutt 1896, = Poaphilini in Beck 1996

*Polydesm[idae] Guenée, 1852a: 436 [Pobjdesma Boisduval, 1833], junior homonym of Polydesmidae Leach, 1815 (Myriapoda, Diplopoda), formed from the generic name Polydesmus Latreille, [1802] having the same stem., (Speidel \& Naumann 1995), (Walker 1858, Cotes \& Swinhoe 1888, Kirby 1897), = Polydesmini in Speidel \& Hassler 1989, Wiltshire 1990, Berio 1992, Beck 1996, Leraut 1997, Hacker 1999. Lophotalia Hampson, 1926 is the nearest genus according to present knowledge (Berio 1960). The name of the family-group could be formed from that name. Pericym[ini] Wiltshire, 1976 is the oldest name for the group, if Berio's opinion is right that the genera Pericyma, Lophotavia, and Polydesma form a monophylum (Berio 1960, 1992)

Remig[idae] Guenée, 1852b: 312 [Remigia Guenée, 1852], eventually a synonym of Wocis Hübner, [1823] 1816 (cf. Poole 1989)], (Walker 1858, Cotes \& Swinhoe 1888, Pagenstecher 1894, Kirby 1897, Noore 1884-7), = Remigini in Wiltshire 1990, = Mocisini Berio, 1992 (syn. nov.)

Rival[ini] Grote, 1895: 419 [Rimla Guenee, 1854], (Bömer 1949, Wiltshire 1990, Hacker 1999) = Rivulinae in Speidel \& al. 1996a. Presently regarded as an independent subfamily.

Scodionyg[ini] Wiltshire, 1976: 209 (original spelling: Scodionychini) [Scodionyx Staudinger, 1899], definition des "Phylum di Scodionyx" in Berio 1960: 303, (Wiltshire 1990), = Scodionysini in Berio 1992, Hacker 1999

Scolecocamp[inae] Grote, 1883: 148 [Scolecocampa Guenée, 1852]

Scoliopteryg[inae] Herrich-Schäffer, [1852]: 21 (original spelling: Scoliopteryges (Gonopteridae)) [Scoliopteryx Germar, 1810] = Scoliopteryginae in Spuler 1907 (Spuler 1901-1908), Börner 1932, Forbes 1954, Fibiger \& Hacker 1990, Beck 1996, see Gonopter[idae] Herrich-Schäffer, [1850] 1845

*Sphingomorph[ini] Wiltshire, 1990: 224 [Sphingomorpha Guenée, 1852], nomen nudum according to article 13.1. ICZN, (Berio 1992, Hacker 1999)

Stictopter[ini] Hampson, 1894: 396 [Stictoptera Guenée, 1852] independent subfamily, = Stictopterini in Grote 1895, = Odontodinae Hampson, 1918 
Syned[ini] Forbes, 1954: 362 [Syneda Guenée, 1852 a synonym of Drasteria Hübner, 1818)]. Synonym of Euclidi[idae] Guenée, 1852 (Speidel \& Naumann 1995), (Beck 1996, Wiltshire 1976, Speidel \& Hassler 1989, Hacker 1999)

Tachos[ini] Berio, 1992: 297, 300 [Tachosa Walker, 1869], definition of the „Phylum di Tachosa" in Berio 1960: 313

Thermesi[idae] Guenée, 1852b: 342 [Thermesia Hübner, 1823], (Walker 1858, Cotes \& Swinhoe 1888, Moore 1884-7, Pagenstecher 1894, Kirby, 1897)

*Thiacid[ini] Berio, 1992: 295, 298 [Thiacidas Walker, 1855], nomen nudum according to article 13.1. ICZN Thysani[ini] Grote, 1895: 422 [Thysania Dalman, 1824], (Leraut 1997)

Tinoli[idae] Moore, [1885] 1884-7: 184 [Tinolius Walker, 1855], synonym von Euclidi[idae] (Speidel \& Naumann 1995)

Toxocamp[idae] Guenée, 1852a: 419 [Toxocampa Guenée, 1841], (Walker 1858, Cotes \& Swinhoe 1888, Kirby 1897), = Toxocampini [Lygephilini] in Börner 1932 (first used in the 4 th edition), = Toxocampini in Grote 1895, Börner 1949, Speidel \& Hassler 1989, Wiltshire 1990, Beck 1996, Leraut 1997, Hacker 1999, = Toxocampina in Beck 1996, = Toxocampinae in Grote 1882, = Lygephilini Wiltshire, 1976 (syn. nov.)

*Trisul[ini] Wiltshire, 1990: 225 [Trisula Moore, 1858], nomen nudum according to article 13.1 ICZN

Tyt[ina] Beck, 1996: 5, 15, 49 [Tjta Billberg, 1820], = Tytinae in Speidel, Fänger \& Naumann 1996a, = Tytini in Leraut 1997

Yrias[idae] Guenée, 1852b: 20 (original spelling: Yriadae) [Yrias Guenée, 1852 (= Metria Hübner, [1823])], described as subfamily of Hypogramm[idae] Guenée, 1852.

This list includes all family group names of Catocalinae s. 1. published until December, 2002, with the references to the first valid use of every name which we could find. There are no published catalogues containing these references, and so we may not have indicated the oldest reference in every case. We hope that minor errors are excusable in this first attempt and welcome every correction.

\section{Acknowledgements}

We thank Prof. C. M. Naumann (Bonn), and Dr. J. Yela (Toledo), for kind reviews of the manuscript which resulted in an improved final version. Our colleague Dr. J. Dutlop kindly corrected the English language for us.

The first author thanks to the German Federal Ministry of Education and Research (BMBF, BIOLOG programm, BIOTA E 06) and the second author to the German Research Council (DFG, reference No. NA 90/17) for financial support.

\section{Literature}

BANG-HAAS, O. 1926: Novitates Macrolepidopterologicae. Katalog der im "Seitz" nicht enthaltenen und seitdem neu beschriebenen palaearktischen Macrolepidopteren. - Gottesberg (Schlesien): Oskar Hensel, $238 \mathrm{pp}$.

BARNES, W. \& BENJAMIN, F. H. 1923: Notes and new species. - Contributions to the Natural History of Lepidoptera of North America 5: 53-96.

BECK, H. 1960: Die Larvalsystematik der Eulen (Noctuidae). - Abhandlungen zur Larvalsystematik der Insekten 4: 1-406.

BECK, H. 1996: Systematische Liste der Noctuidae Europas (Lepidoptera, Noctuidae). - Neue Entomologische Nachrichten 36: 1-122.

BERIO, E. 1955: Contribution à l'étude des Noctuidae de Madagascar. - Mémoires de l'Institut Scientifique de Madagascar (E) 6: 109-140.

BERIO, E. 1960: Studi sulla sitematica delle cosiddette "Catocalinae" e "Othreinae" (Lepidoptera, Noctuidae). - Annali del Museo Civico di Storia Naturale Giacomo Doria 71: 276-327. 
BERIO, E. 1965: Le Catocaline Africane a tibie spinose del Museo di Tervuren. - Annali del Museo Civico di Storia Naturale Giacomo Doria 75: 181-332.

BERIO, E. 1992: Ricerca di possibili modelli sistematici per le Catocalinae e Ophiderinae del globo (Lepidoptera, Noctuidae). - Memorie della Societa Entomologica Italina 70 (2): 287-303. Remark: In the edition of volume 70 (2) of this journal is wrong printed the information 1991. In the head of the paper is note the date 29.2.1992. For this reason the date of publication has to be 1992, according article 22 ICZN.

BERIO, E. \& FLETCHER, D. S. 1958: Monographia dell'antico genere Sppna GUEN. (Lepidoptera - Noctuidae). - Annali del Museo Civico di Storia Naturale Giacomo Doria 70: 323-402.

Boisdeval, J. A. 1829: Europaeorum Lepidopterorum Index Methodicus. - Paris, Bruxelles: 103 pp.

BoisDuvil, J. A. 1833: Faune Entomologique de Nadagascar, Bourbon \& Maurice, Lépidoptères. - Paris. 122 pp. $+\mathrm{iv}, 16$ plates.

Boisduval, J. A. 1874: Monographie des Agaristidées (Lépidoptères). - Revue et Magazin de Zoologie, serie 3, 2: 26-110.

BORKHALSEN, M. B. 1792: Naturgeschichte der Europäischen Schmetterlinge nach Systematischer Ordnung. 4. Der Phalaenen zweite Horde. Eulen. - Frankfurt: Barrentrapp und Wenner, 809 pp.

BÖRNER, C. 1932: Lepidoptera. - pp. 382-420. - In: BROHMER, P.: Fauna von Deutschland. 4., verbesserte Auflage, Heidelberg: Quelle \& Meyer, 584 pp.

BÖRNER, C. 1939: Die Grundlagen meines Lepidopterensystems. VII. Internationaler Kongress für Entomologie, Verhandlungen 2 (herausgegeben von JORDAN, K. \& HERING, E. M.): 1372-1424.

BÖRNER, C. 1944: Lepidoptera. - pp. 382-420. - In: BROHMER, P.: Fauna von Deutschland. 5., verbesserte Auflage, Heidelberg: Quelle \& Meyer, $584 \mathrm{pp}$.

BÖrNer, C. 1949: Lepidoptera. - pp. 369-404. - In: Bromier, P.: Fauna von Deutschland. 6., verbesserte Auflage, Leipzig: Quelle \& Meyer, 561 pp.

ButLer, A. G. 1878: On a collection of Lepidoptera recently received from Madagscar. - Annals and Magazine of Naturale History, series 5, 2: 283-297.

COMMON, I. F. B. 1968: Lepidoptera (Moths and Butterflies), - pp. 765-866. - In: MACKERRAS, I. M.: Insects of Australia. Canberra: $1029 \mathrm{pp}$.

COMMON, I. F. B. 1990: Moths of Australia. - Melbourne: University press, 535 pp.

Cotes, E. C. \& SwinhoE, C. 1888: A catalogue of the moths of India. Part 3. Noctues, Pseudo-Deltoides, and Deltoides, 257-461, Calcutta, Indian Museum.

CRLmB, S. E. 1956: The larvae of the Phalaenidae. - Technical Bulletin of United States Department of Agriculture 1135: 1-365.

DeNiS, J. N. C. M. \& SCHifFERMÜLleter, I. 1775: Ankündung eines systematischen Werkes von den Schmetterlingen der Wienergegend herausgegeben von einigen Lehrern am $\mathrm{k}$. $\mathrm{k}$. Theresianum. Wien: Augustin Bernardi, 323 pp., plate 1 a and b.

DraUDT, M. \& GAEDE, M. 1944: Unterfamilie: Noctuinae. pp. 471-511. - In: SEI'IZ, A. (1919-1944): Die Gross-Schmetterlinge der Erde, 7. Die Gross-Schmetterlinge des Amerikanischen Faunengebietes. Eulenartige Nachtfalter. - Stuttgart: Alfred Kernen, 511 pp., 96 plates.

DraUdT, M. 1935: Unterfamilie: Catocalinae, Phytometrinae, Noctuinae. pp. 206-358. - In: SEITZ, A. (19131940): Die Gross-Schmetterlinge der Erde, 15. Die Gross-Schmetterlinge des Afrikanischen Faunengebietes, Eulenartige Nachtfalter. - Stuttgart: Alfred Kernen, iii 358 pp., 41 plates.

DRAUDT, M. 1939: Unterfamilie: Catocalinae. pp. 417-461. - In: SEITZ, A. (1919-1944): Die GrossSchmetterlinge der Erde, 7. Die Gross-Schmetterlinge des Amerikanischen Faunengebietes. Eulenartige Nachtfalter: - Stuttgart: Alfred Kernen, 511 pp., 96 plates.

Duponchel, M. P. A. J. 1844: Catalogue Méthodique des Lépidoptères d'Europe. - Paris: 523 pp.

DYAR, H. G. 1902: A list of North American Lepidoptera and key to the Literature of this order of Insects. - Bulletin of the United States National Museum 52: 1-723.

Dyar, H. G. 1914: Report on the Lepidoptera of the Smithsonian Biological survey of the Panama Canal Zone. - Proceedings of the United States National Museum 47: 139-350.

EGGERS, F. 1919: Das thoracale bitympanale Organ einer Gruppe der Lepidoptera Heterocera. Zoologisches Jahrbuch (Abteilung für Anatomie) 41: 273-376. 
EGGERS, F. 1925: Versuche über das Gehör der Noctuiden. - Zeitschrift für vergleichende Physiologie 2: 297-314.

Fang, Q. Q.; Mitchell, A.; Regier, J. C.; Mitter, C.; Friedlander, T. P. \& Poole, R. W. 2000: Phylogenetic utility of the Nuclear gene Dopa Decarboxylase in Noctuoid Moths (Insecta: Lepidoptera: Noctuoidea). - Molecular Phylogenetics and Exolution 15 (3): 473-486.

FibigER, M. 1990: Noctuidae Europaeae. 1. Noctuinae 1. - Sorø, Denmark: Entomological press, 208 pp.

FIBIGER, M. \& HACKER, H. 1990: Systematic List of the Noctuidae of Europe. - Esperiana 2: 1-108.

FLETCHER, D. S. \& NYE, I. W. B. 1982: The generic names of moths of the world, edited by I. W. B. NYE, Volume 4, Bombycoidea, Mimallonoidea, Castnioidea, Seioidea, Cossoidea, Sphigoidea, Zygaenoidea. London: Unwin Brothers Ltd, 192 pp., 1 plate.

FORBES, T. M. 1914: A table of the genera of Noctuidae of Northeastern North Amerika. - Journal of the New Yorck Entomological Society 22 (1):1-33.

ForBes, T. M. 1916: On the tympanum of certain Lepidoptera. - Psyche 23: 183-192.

FORBES, W. T. M. 1954: Lepidoptera of New York and neighboring states, Noctuidac. 3. - Cornell University Agricultural experiment station: 1-433.

GAEDE, M. 1936-1937: Subfamilie: Catocalinae. pp. 206-256. - In: SErrZ, A. (1913-1940): Die GrossSchmetterlinge der Erde, 15. Die Gross-Schmetterlinge des Afrikanischen Faunengebietes. Eulenartige Nachtfalter. - Stuttgart: Alfred Kernen, iii 358 pp., 41 plates.

GAEDE, M. 1938: Subfamilie: Catocalinae. pp. 454-496. - In: SEITZ, A. (1912-1938): Die Gross-Schmetterlinge der Erde, 11. Die Gross-Schmetterlinge des Indo-australischen Faunengebietes. Eulenartige Nachtfalter. Stuttgart: Alfred Kernen, ii +496 pp, 56 plates.

GARDNER, J. C. M. 1947: On the Larvae of the Noctuidae - III. - Transaction of the Royal Entomoligical Society of London 98: 59-90.

GRTVEAUD, P. \& VIETTE, P. 1961: Nouvelles espèces malgaches de Noctuelles quadrifides (Lépidoptères). Bulletin de l'Academie Malgache, new series 38: 53-62, 1 plate.

Grote, A. R. 1882: New checklist of North American moths. - 73 pp. no publishing company indicated.

Grote, A. R. 1883: Introduction to a study of the North American Noctuidae. - Proceedings of the American Philosophical Society 21: 134-176.

Grote, A. R. 1889: The Noctuidae of Notth America and Europe. - Canadian Entomolgist 21: 121-126, 154-157, 188-193, 226-230.

Grote, A. R. 1890a: The Noctuidae of North America and Europe. - Canadian Entomolgist 22: 26-30, $69-72,105-109,145-149$.

Grote, A. R. 1890b: North American Lepidoptera. Revised Check List of the North American Noctuidae, Part 1. Thyatirinae-Noctuinae. - Bremen: Homeyer and Meyer, 52 pp.

Grote, A. R. 1895: The hypenoid moths and allied groups. - Proceedings of the American Philosophical Society 34: 416-436.

GROTE, A. R. 1896a: System der nordamerikanischen Schmetterlinge (List of Superfamilies and families and their types). - Mittheilungen aus dem Roemer-Museum, Hildesheim 7: 1-4.

Grote, A. R. 1896b: List of North American Eupterotidae, Ptilodontae, Thyatiridae, Apatelidae and Agrotidae. - Abhandlungen hrsg. vom naturwissenschaftlichen Verein zu Bremen 14 (1): 44-128.

GUENEE, A. 1837: Essai pour servir à la classification des Noctuèlides (suite). - Annales de la Société Entomologique de France 6: 311-367.

GUenEE, A. 1841: Essai sur la classification des Noctuèlides (suite et fin.). - Annales de la Société Entomologique de France 10: 217-250.

Guenée, A. 1852a: Noctuélites, 2. - In: Boisduval, J. B. A. D. \& Guenée, A. (Hrsg.): Histoite Naturelle des Insectes. Species Général des Lépidoptères. 6. - Paris: Librairie Encyclopédique de Roret, 444 pp.

Guenée, A. 1852b: Noctuélites, 3. - In: Borsovval, J. B. A. D. \& Guenée, A. (Hrsg.): Histoire Naturelle des Insectes. Species Général des Lépidoptères. 7. - Paris: Librairie Encyclopédique de Rotet, 442 pp., 24 plates. 
GUENÉE, A. 1854: Deltoides et Pyralites. Histoire Naturelle des Insectes. Species Général des Lépidoptères, 8. - Paris: Librairie Encyclopédique de Roret, 448 pp., 10 plates.

HACKER, H. 1990: Die Noctuidae Vorderasiens (Lepidoptera). - Neue Entomologische Nachrichten 27: 1-707. HACKER, H. 1999: Systematic List of the Lepidoptera of the Arabian Peninsula with survey of the spread with special refernce to the fauna of Yemen. - Esperiana 7: 15-237.

Hampson, G. F. 1894: The fauna of British India, including Ceylon and Burma, Moths. 2. - London: Taylor and Francis, 609 pp.

HAMPSON, G. F. 1895: The fauna of British India, including Ceylon and Burma, Moths. 3. - London: Taylor and Francis, $546 \mathrm{pp}$.

HANPSON, G. F. 1902: The Moths of South Africa (Part II.). - Annals of the South African Museum 2: $255-446$.

HAMPSON, G. F. 1910: Zoological collections from Northern Rhodesia and adjacent territories: Lepidoptera Phalaenae, - Proceedings of the Zoological Society of London, 1910: 388-510, plates 36-41.

HAMpson, G. F. 1913: Catalogue of the Lepidoptera Phalaenae in the British Museum. Volume 13. London: Taylor and Francis, 609 pp., plates 222-239.

HAMPSON, G. F. 1918: Some small families of the Lepidoptera which are not included in the key to the families in the Catalogue of Lepidoptera Phalaenae, a list of the families and subfamilies of the Lepidoptera with their types and a key to the families. - Novitates Zoologicae 25: 366-394.

HAwORTH, A. H. 1803-1823: Lepidoptera Britannica: part 1: 1-136 (1803), part 2: $137-376$ (1809), part 3: 377-511 (1811), patt 4: 512-609 (1823), London: R. Taylor.

HEMMING, F. 1937: Hübner. A bibliographical and systemtic account of the entomological works of Jacob Hübner and of the supplements thereto by Carl Geyer, Gottfried Franz von Frölich and Gottlieb August Wilhelm Herrich-Schäffer. Volume 1. - Suffolk: Richard Clay \& Sons, 605 pp.

HEPPNER, B. 1991: Faunal regions and the diversity of Lepidoptera. - Tropical Lepidoptera 2: 1-85.

HERRICH-SCHÄFfER, G. A. W. 1843: Systematische Bearbeitung der Schmetterlinge von Europa, zugleich als Text, Revision und Supplement zu Jakob Hübnet's Sammlung europäischer Schmetterlinge. 1. Die Tagfalter. - Regensburg: 164 pp., 134 plates Papilionides +7 plates Hesperides.

HERRICH-SCHÄFFER, G. A. W. 1845 [1845-1855]: Systematische Bearbeitung der Schmetterlinge von Europa, zugleich als Text, Revision und Supplement zu Jakob Hübner's Sammlung europäischer Schmetterlinge. 2. Die Schwärmer, Spinner und Eulen. - Regensburg: 450 pp., 1 plate Hepialides +2 plates Cossides and/or Hepialides \& Cossides +16 plates Zygaenides +10 plates Sesiides +4 plates Sphingides +32 plates Bombycides +124 plates Noctuides +1 plates Nycteolidae.

HERRICH-SCHÄFFER, G. A. W. 1847 [1843-1856]: Systematische Bearbeitung der Schmetterlinge von Europa, zugleich als Text, Revision und Supplement zu Jakob Hübner's Sammlung europäischer Schmetterlinge. 3. Die Spanner. - Regensburg: 184 pp., 91 plates.

HERRICH-SCHÄFFER, G. A. W. 1843-1856: Systematische Bearbeitung der Schmetterlinge von Europa, zugleich als Text, Revision und Supplement zu Jakob Hübner's Sammlung europäischer Schmetterlinge. $6.4 \mathrm{pp}$. (Schlusswort) $+18 \mathrm{pp}$. (Erläuterung der Tafeln mit Umrissen) with 22 plates, $+8 \mathrm{pp}$. (Erläuterung der Tafeln mit Umrissen zu den Microlepidopteren) with 14 plates $+178 \mathrm{pp}$. (Nachträge) $+72 \mathrm{pp}$. (Systema Lepidopterotum Europae. Systematisches Verzeichnis det Europäischen Schmetterlinge) + 24 Seiten (Index alphabetico-synonymicus ad vol. 1) + 64 pp. (Index alphabetico-synonymicus ad vol. 2) $+34 \mathrm{pp}$. (Index alphabetico-synonymicus ad vol. 3) + $48 \mathrm{pp}$. (Index alphabetico-synonymicus ad vol. 4) + 52 pp. (Index alphabetico-synonymicus ad vol. 5) + 48 pp. (Index universalis). Regensburg.

Hodges, R. W; Dominick, T.; Davis, D. R.; Ferguson, D. C.; Franclemont, J. G.; Munroe, E. G.; PolvelL, J. E. 1983: Check List of the Lepidoptera of America North of Mexico. - London: 284 pp.

Hollowny, J. D.; KibBy, G. \& PEGGY, D. 2001: The families of Malesian moths and Butterflies. - In: DE WiNTER, A. J. (Hrsg.): Fauna Malesiana Handbooks. 3. - Leiden, Boston, Köln: Brill, 455 pp.

HÜBNER, J. 1816 [1816-1826]: Verzeichniß bekannter Schmettlinge [sic]. 431 pp. +72 pp. (Anzeiger' = Index, [1826]), Augsburg.

INOUE, H. 1958: Check list of the Lepidoptera of Japan. 5. Noctuidae, in collaboration with Shigero Sugi. - Rikusuisha, Tokyo: 431-619. 
Inoue, H.; Sugi, S.; Klroko, H.; Moridti, S. \& KAwAbE, A. 1982: Moths of Japan. 2. - Tokyo, Kodansha: 552 pp., 392 pl.

IZCN: (1999) International Code of Zoological Nomenclature. 4. Edition. - Padova (Italy): Tipografia La Garangola, $306 \mathrm{pp}$.

JANSE, A. J. T. 1917: Check-List of the South African Lepidoptera Heterocera. - Pretoria: Buckley \& Van Duyn printers, $219 \mathrm{pp}$.

KIRBY, W. F. 1897: A hand-book to the order Lepidoptera. - London: Edward Lloyd, 332 pp.

KIRBY, W. F. 1907: The butterflies and moths of Europe. - London: 432 pp.

KiRIakofF, S. G. 1951: Recherches sur les organes tympaniques des Lépidoptères en rapport avec la classification. VIII. Cocytiidae. - Entomologische Betichte 13: 381-382.

KIRLAKOFF, S. G. 1956: Recherches sur les organes tympaniques des Lèpidoptères en tapport avec la classification. - Bulletin et Annales de la Société Royale Belge d'Entomologie 92: 168-199.

KrrchING, I. J. 1984: An historical review of the higher classification of the Noctuidae (Lepidoptera). Bulletin of British Museum Natural History (Entomolgy) 49 (3): 153-234.

Kitching, I. J. \& Railins, J. E. 1999: The Noctuoidea. pp. 355-401. - In: KRISTENSEN, N. P., 1999 Lepidoptera, Moths and Butterflies. 1. Evolution, Systematics, and Biogeography. - New York, Berlin: $491 \mathrm{pp}$.

Kobes, L. W. R. 1985: Die Thyatiridae, Agaristidae und Noctuidae (Teil 1: Pantheinae und Catocalinae) von Sumatra. in Diehl, E.W. Hetroceara Sumatrana, 4. - Keltern: Erich Bauer, 92 pp., 22 pl.

KONONENKO, V.S. 1990: Synonymic check list of the Noctuidae of the Primorye Territory, the Far East of U.S.S.R. Tinea 13 (Supplement 1): $1-40$.

LEACH, W. E. 1815: Entomology. pp. 57-172. - In: BREWSTER, D., Edinburgh Encyclopaedia. 9. - Edinburgh, $766 \mathrm{pp}$.

LEDERER, J. 1857: Die Noctuinen Eutopas mit Zuziehung einiger bisher meist dazu gezählter Arten des asiatischen Russland's, Kleinasien's, Syrien's und Labrador's. - Wien: Friedrich Manz, 251 pp.

LEECH, J. H. 1900: Lepidoptera Hetrocera from Northern China, Japan and Corea, part IV. - Transaction of the Entomological Society of London 33: 511-663.

LERAUT, J. A. 1980: Liste systématique et synonymique des Lépidoptères de France, Belgique et Corse. Alexanor, Supplement: 1-334.

LERIUT, J. A. 1997: Liste systèmatique et synonymique des Lépidoptères de France, Belgique et Corse (Deuxième èdition). - Alexanor, Supplement: 1-526.

LhONINE, L. 1923-1935: Catalogue des Lépidoptères de France et de Belgique 1 (Macrolépidoptères). Paris: Le Carriol, par Douelle, (Lot), $800 \mathrm{pp}$.

MCDUNNough, J. H. 1938: Check List of the Lepidoptera of Canada and United States of America. Part 1. - Memoirs of the southern California Academy of Sciences 1: 1-275.

MEYRICK, E. 1895: A Handbook of the British Lepidoptera. - London: Macmillan and Co., 843 pp.

MEYRICK, E. 1912: A revision of the classification of the New Zealand Caraditinina. - Transaction of the New Zealand Institute 44: 88-107.

Mitchell, A.; MitTer, C. \& REGIER, J. 2000: More taxa and more characters revisited: Combining data from nuclear protein-encoding genes for phylogenetic analyses of Noctuoidea (Insecta: Lepidoptera). - Systematic Biology 49: 202-224.

Moore, F. 1884-1887: The Lepidoptera of Ceylon, 3. - London: L. Reeve \& Co., 578 pp., 144-215 pl. MOSHER, E. 1916: A classification of the Lepidoptera based on characters of the pupa. - Bulletin of the Illinois State Laboratory Natural History 12: 17-159.

Nitelsen, E. S.; EDWARDS, E. D. \& RANGSI, T. V. 1996: Monographs on the Australian Lepidoptera. 4, Checklist of the Lepidoptera of Australia. - Australia: CSIRO Publishing, 529 pp.

NYE, I. W. B. 1975: The generic names of moths of the world. Volume 1. Noctuoidea (part): Noctuidae, Agaristidae, and Nolidae. - London: Unwin Brothers Itd, 568 pp., 1 plate.

PACKARD, A. S. 1869: The characters of the Lepidoptera. - The American Naturalist 29: 636-647, 788-803.

PAGeNstecher, A. 1894: Beiträge zur Lepidopteren-Fauna des malayischen Archipels (IX), 1. Über Javanische Schmetterlinge. - Jahrbücher des Nassauischen Vereines für Naturkunde 47: 27-51. 
PiNhey, E. C. G. 1975: Moths of Southern Africa. - Cape Town: 273 pp.

PoOLE, R. W. 1989: Lepidopterorum Catalogus (New Series), Fascicle 118, Noctuidae part 1: 1-500, part 2: 501-1014, part 3: 1015-1314. - Leiden, New York, Kobenhavn, Köln: E. J. Brill, Flora \& Fauna Publications.

PoOt., R. W. 1994: Noctuoidea, Noctuidae (part). Cuculliinae, Stiriinae, Psaphidinae. - In: DomINICK, R. B., \& al:: The moths of America North of Mexico, fasc. 26.1. - Washington: 294 pp.

Prout, A. E. 1921: Notes on some Noctuidae in the Joicey Collection, with descriptions of new species. Annales and Magazin of Natural History, series 9 8: 1-33, plates 1-7.

PROUT, A. E. 1922: On some apparently new species and forms of Noctuidae. Collected by C. F. and J. Pratt, in the mountains of Central Ceram, October, 1919, to February, 1920. - Bulletin of the Hill Museum 1: 193-251.

Prout, A. E. 1928: Descriptions of some Indo-Australian Noctuidae. - Bulletin of the Hill Museum 2: $63-$ $74,161-176$.

REBEL, H. 1898: Ueber den gegenwärtigen Stand der Lepidopteren-Systematik. - Deutsche Entomolgische Zeitschrift Iris 11: 377-391.

RichARos, A. G. 1933: Compatative skeletal morphology of the Noctuid tympanum. - Entomological Americana 13 (1): 1-43, 20 plates.

SEITZ, A. 1937: Subfamilic Eutelianae, pp. 351-352. - In: SEITZ, A. (1912-1938): Die Gross-Schmetterlinge der Erde, 11. Die Gross-Schmetterlinge des Indo-australischen Faunengebietes. Eulenartige Nachtfalter. - Stuttgart: 496 pp., 56 pl.

SmITH, J. B. 1893: A Catalogue Bibliographical and Synonymical of the Sepcies of Moths of the Lepidopterous Superfamily Noctuidae found in Boreal America. - Bulletin of the United States National Museum 44: 1-424.

SPEIDEL, W. \& HASSLER, M. 1989: Die Schmetterlingsfauna der südlichen algetischen Sahara und ihrer Hochgebirge Hoggar und Tassili n'Ajjer. - Nachtichten des Entomologischen Vereins Apollo, Supplement 8: $1-156$.

SPEIDEL, W. \& NAUMANN, C. M. 1995: Phylogenetic aspects in the higher classification of the subfamily Catocalinae (Lepidoptera, Noctuidae). - Beiträge zur Entomologie 45: 109-118.

SPEIDEL, W; FRNGER, H. \& NAUMANN, C. M. 1996a: The phylogeny of the Noctuidae (Lepidoptera). Systematic Entomolgy 21: 219-251.

SPEIDEI, W; FANGER, H. \& NALMANN, C. M. 1996b: The surface microstructure of the noctuid proboscis (Lepidoptera: Noctuidae). - Zoologischer Anzeiger 234: 307-315.

SPEIDEL, W.; FÄNGER, H. \& NAUMANN, C. M. 1997: On the systematic position of Cocytia (Lepidoptera, Noctuidae). - Deutsche Entomologische Zeitung, N. F., 44: 27-31.

Spuler, A. 1901-1908: Die Schmetterlinge Europas. 1 cxxviii +385 pp. (page 297, Druckbogen 38, 1907), Stuttgart.

STALDINGER, O. \& WOCKE, M. F. 1871: Catalog der Lepidopteren des europäischen Faunengebietes. xxxviii +426 pp. (Macrolepidoptera, page 1-200 (by STAUdinGER), Microlepidoptera, page 201-346 (by Wocke), Dresden.

Staldinger, O. \& Rebel, H. 1901: Catalog der Lepidopteren des palaeartischen Faunengebietes (3. Auflage). 1.Theil, xxxii +411 pp. (by Staudinger \& Rebel), 2. Theil, 368 pp. (by Rebel), Berlin: Friedländer \& Sohn.

Sugi, S. 1992: Catocalinae. Pp. 175-183. - In: Heppner, J. B., Inove, H. (1982) Lepidoptera of Taiwan, 1 (2). Checklist. - Gainesville: Scientific publishers, xlix $+276 \mathrm{pp}$.

SWINHOE, C. 1899: New species of Oriental Lepidoptera. - Annals and Magazine of Natural History, series 7, 3: 102-116.

Turner, A. J. 1920: A revision of Australian Noctuidae. - Transaction and Proceedings of the Royal Society of South Australia 44: 120-189.

TurT, J. W. 1896: British Moths. - London: Routledge \& Sons, 368 pp.

WALKER, F. 1857-1858: List of specimens of lepidopterous insects in the collection of the British Museum. 12 ([1858] 1857, page 766-982), 13 ([1858] 1857, page 983-1236), 14 (1858, page 1237-1519), 15 (1858, page 1520-1888), 16 ([1859] 1858, page 1-253) (Noctuidae-Teile), London. 
WARREN, W. 1909: 2. Familie: Noctuidae, pp. 9-66. - In: SEITZ, A. (1909-1914): Die Gross-Schmetterlinge der Erde, 3. Die Gross-Schmetterlinge des palaearktischen Faunengebietes. Die eulenartigen Nachtfalter, iii +511 pp., 75 pl. Alfred Kernen, Stuttgart.

WARREN, W. 1913: Subfamilie: Catocalinae. pp. 301-344. \& Noctuinae. pp. 359-444. - In: SEITZ, A. (19091914): Die Gross-Schmetterlinge der Frde, 3. Die Gross-Schmetterlinge des Palaearktischen Faunengebietes. Die eulenartigen Nachtfalter. - Stuttgart: Alfred Kernen, iii +511 pp., 75 pl.

Werneburg, A. 1864a: Beiträge zur Schmetterlingskunde. Kritische Bearbeitung der wichtigsten entomologischen Werke des 17. und 18. Jahthunderts bezüglich der darin abgehandelten Europäischen Schmetterlinge. 1, - Erfurt: H. Neumann, 595 pp.

WerneburG, A. 1864b: Beiträge zur Schmetterlingskunde. Kritische Bearbeitung der wichtigsten entomologischen Werke des 17. und 18. Jahrhunderts bezüglich der darin abgehandelten Europäischen Schmetterlinge. 2. - Erfurt: H. Neumann, 347 pp.

WiLTSHIRE, E. P. 1961: Middle East Lepidoptera, XVI: a new genus, eight new species, seven new forms, and notes on the Lepidoptera of Saudi Arabia, Baharian and Iran. - Journal of the Bombay Natural History Society 58 (3): 608-631.

WILTSHIRE, E. P. 1970: Middle East Lepidoptera XVIII. A review of the genus Pericyma Herrich-Schäffer and neighbouring genera and especially their relationship as shown by their genitalia, with a description of a new species from Abyssinia (Lepidoptera, Noctuidae). - Veröffentlichungen der Zoologischen Staatssammlung München 14: 91-119.

WILTSHIRE, E. P. 1971: Middle East Lepidoptera XXVII. Österteichische Expeditionen nach Persien und Afghanistan Beiträge zur Lepidopterenfauna, Teil 15. Noctuidae-Quadrifinae. - Annalen des Naturhistorischen Museums in Wien 75: 627-649.

WIITSHIRE, E. P. 1976 [1977]: Middle East Lepidoptera, XXXII: Diagnosis of some eremic tribes of Noctuidae-Quadrifinae, with a discussion of their biogeographical significance. - Journal of the Bombay Natural History Society 73 (1): 157-165.

Wiltshre, E. P. 1979: A revision of the Armadini (Lepidoptera, Noctuidae). 78 pp. Entomonograph Volume 2, - Denmark: Scand. Science Press, Klampenborg.

Wiltshire, E. P. 1990: An illustrated, annoted Catalogue of the Macro-Heterocera of Saudi Arabia. Fauna of Saudi Arabia 11: 91-250.

YELA, J. L. 1997: Noctuidos del área Tberobalear: Adiciones y correcciones a la lista sistemática, con consideraciones micro y macroevolutivas y una propuesta filogenética global (Insecta: Lepidoptera: Noctuidae). - Zapateri Revista aragonesa de Entomologia 7: 91-190.

YeLA, J. L. \& KItChing, I. J. 1999: Noctuid phylogeny revisited (Insecta: Lepidoptera: Noctuidae). Boletin de la Sociedad Entomogica Aragonesa 26: 509-520 (in spanish 485-508).

ZIMNERMAN, E. C. 1958: Insects of Hawaii. 7. Macrolepidoptera. - Honolulu: 542 pp.

\section{Author's addresses:}

LARS KÜHNE

Museum für Naturkunde der Humboldt Universität zu Berlin

Invalidenstraße 43, D-10115 Berlin, Germany

(Lars.Kuehne@MUSEUM.HU-Berlin.de)

Dr. WOIFGANG SPEIDEL

Zoologisches Forschungsinstitut und

Museum Alexander Koenig

Adenauerallee 160, D- 53113 Bonn, Germany

(W.Speidel.ZFMK@Uni-Bonn,de) 